\title{
STAGES OF CARBONIFEROUS-TRIASSIC MAGMATISM IN THE BLACK SEA REGION BASED ON ISOTOPE-GEOCHRONOLOGICAL STUDY OF DETRITAL ZIRCONS FROM JURASSIC COARSE CLASTIC STRATA OF THE MOUNTAINOUS CRIMEA
}

\author{
T.V. Romanyuk $\oplus^{1}$, N.B. Kuznetsov $\oplus^{2 \otimes}$, S.V. Rud'ko $\oplus^{2}$, A.A. Kolesnikova $\oplus^{2}$, D.V. Moskovsky $\oplus^{2,3}$, \\ A.S. Dubensky $\oplus^{2,3}$, V.S. Sheshukov $\oplus^{2}$, S.M. Lyapunov $\oplus^{2}$
}

\author{
${ }^{1}$ Schmidt Institute of Physics of the Earth, Russian Academy of Sciences, 10/1 Bolshaya Gruzinskaya St, Moscow \\ 123242, Russia \\ ${ }^{2}$ Geological Institute, Russian Academy of Sciences, Moscow, 7 Pyzhevsky Ln, Moscow 119017, Russia \\ ${ }^{3}$ Lomonosov Moscow State University, 1 Leninskie Gory, Moscow 119991, Russia
}

\begin{abstract}
The article presents the results of $\mathrm{U}-\mathrm{Pb}$ isotope dating of detrital zircons from the Jurassic coarse rocks in the apex and the western slope of Mnt. Biyuk-Sinor (the southern wall of the Baidar basin, near the village of Orlinoe). These dates are compared with the detrital zircon dates obtained for sandy rocks from the Upper Jurassic coarse clastic strata composing the slopes of Mnt. Spilia near Balaklava Harbor and Mnt. Southern Demerdzhi near Alushta city, as well as the Middle Jurassic Bitak conglomerates near the village of Strogonovka (suburb of Simferopol city). The comparison shows a high degree of similarity of the averaged age characteristics of the main detrital zircon populations. Sandy rocks of Jurassic coarse clastic strata for zircon dating were sampled in four locations of the Mountaineous Crimea. Based on their dates and a summary set of ages of detrital zircon grains from sandstones of the Southern Coast of Crimea, spanning the stratigraphic interval from the Middle Jurassic to Neogene, we can provide a statistically reliable specification of the Carboniferous-Triassic time interval (360-200 Ma) of magmatic activity within the Black Sea region. This period was bounded in time by the Late Devonian and Early Jurassic relative magmatic lulls. None of the zircon grains of the CarboniferousTriassic age has revealed Hf-isotopic characteristics indicating any significant contribution of crustal material older than the Mesoproterozoic into the protolith of the parent zircon rocks. Within the Carboniferous-Triassic interval of magmatic activity, three stages are distinguished: (I) 360-315 Ma, (II) 315-270 Ma, and (III) 270-200 Ma. Magmatic stage I (360$315 \mathrm{Ma}$ ) is related to the closure of the Reik ocean, which completed after the subducted slab 'broke off' into the mantle and was accompanied by the ubiquitously manifested HT-LP metamorphism. Zircon grains of stage I are characterized by peak ages of about 325-340 Ma and the dominance of negative $\varepsilon_{\mathrm{Hf}}$ Magmatic stages II (315-270 Ma) and III (270-200 Ma) correlate with functioning of the Scythian-Pontian volcanic suprasubduction belt. In these magmatic stages, zircon $\varepsilon_{\mathrm{Hf}}$ values scatter from weakly negative to substantially positive (referred to the depleted mantle), which is typical for volcanic arcs. Fuzzy separation of stages II and III and strong variability of the peak ages of zircons from the studied samples (which we associate with these stages) can be due both to changes in magmatic activity in different segments of the belt, and to changes in the erosion intensity of crystalline complexes of the belt during the subsequent stages evolution caused by tectonic rearrangements within the Paleo-Tethys ocean and its peri-oceanic structures.
\end{abstract}

KEYWORDS: Mountainous Crimea; Jurassic coarse clastic strata; detrital zircons; U-Pb dating; Hf isotopic systematics; trace elements; Carboniferous-Triassic period of magmatic activity; Black Sea region

FUNDING. The study was carried out under the state assignments of Schmidt Institute of Physics of the Earth and the Geological Institute RAS. Isotope analyses and data processing were funded by RFBR (project 19-05-00284).

\section{RESEARCH ARTICLE}

Correspondence: Nikolay B. Kuznetsov, kouznikbor@mail.ru
Received: March 12, 2020

Revised: April 10, 2020

Accepted: April 14, 2020

FOR CITATION: Romanyuk T.V., Kuznetsov N.B., Rud'ko S.V., Kolesnikova A.A., Moskovsky D.V., Dubensky A.S., Sheshukov V.S., Lyapunov S.M., 2020. Stages of Carboniferous-Triassic magmatism in the Black Sea region based on isotope-geochronological study of detrital zircons from Jurassic coarse clastic strata of the Mountainous Crimea. Geodynamics \& Tectonophysics 11 (3), 453-473. doi:10.5800/GT-2020$11-3-0486$ 


\title{
ЭТАПЫ КАМЕННОУГОЛЬНО-ТРИАСОВОГО МАГМАТИЗМА В ПРИЧЕРНОМОРЬЕ ПО РЕЗУЛЬТАТАМ ИЗОТОПНО-ГЕОХРОНОЛОГИЧЕСКОГО ИЗУЧЕНИЯ ЗЕРЕН ДЕТРИТОВОГО ЦИРКОНА ИЗ ЮРСКИХ ГРУБООБЛОМОЧНЫХ ТОЛЩ ГОРНОГО КРЫМА
}

\author{
Т.В. Романюк ${ }^{1}$, Н.Б. Кузнецов ${ }^{2}$, С.В. Рудько ${ }^{2}$, А.А. Колесникова ${ }^{2}$, Д.В. Московский ${ }^{2,3}$, \\ А.С. Дубенский ${ }^{2,3}$, В.С. Шешуков ${ }^{2}$, С.М. Ляпунов ${ }^{2}$ \\ ${ }^{1}$ Институт физики Земли им. О.Ю. Шмидта РАН, 123242, Москва, ул. Большая Грузинская, 10, стр. 1, Россия \\ ${ }^{2}$ Геологический институт РАН, 119017, Москва, Пыжевский пер., 7, Россия \\ ${ }^{3}$ Московский государственный университет им. М.В. Ломоносова, 119991, Москва, Ленинские горы, 1, Россия
}

\begin{abstract}
АНнотАЦИЯ. В статье представлены результаты U-Pb изотопного датирования зерен детритового циркона из толщи юрских грубообломочных пород, залегающих в вершинной части и на западном склоне г. Биюк-Синор (южный борт Байдарской котловины, около села Орлиное). Сопоставление этих датировок с полученными ранее результатами изучения зерен детритового циркона из песчанистых пород, участвующих в строении разрезов верхнеюрских грубообломочных толщ, слагающих склоны г. Спилия около Балаклавской бухты и г. Южная Демерджи около г. Алушты, а также среднеюрских битакских конгломератов около с. Строгановка (пригород г. Симферополя), показало высокую степень сходства осредненных возрастных характеристик основных популяций зерен детритового циркона. Результаты изучения зерен детритового циркона из песчанистых пород юрских грубообломочных толщ в четырех локациях Горного Крыма вместе с аналогичными данными для суммарного набора возрастов зерен детритового циркона из проб песчаников Южного берега Крыма, попадающих в стратиграфический интервал от средней юры до неогена, позволили статистически надежно охарактеризовать каменноугольно-триасовый (360-200 млн лет) интервал магматической активности, проявленной в пределах Причерноморья и ограниченной во времени позднедевонским и раннеюрским относительными магматическими затишьями. Ни в одном из зерен циркона каменноугольно-триасового возраста не выявлены Нf-изотопные характеристики, указывающие на сколько-нибудь значительный вклад корового материала старше мезопротерозоя в протолит материнских пород циркона. В выделяемом каменноугольно-триасовом интервале магматической активности можно обособить три этапа: (I) 360-315 млн лет, (II) 315-270 млн лет и (III) 270-200 млн лет. Этап магматизма I (360-315 млн лет) соотносится с закрытием океана Реик, завершившимся «отрывом и обрушением» субдуцируемого слэба в мантию и сопровождавшимся повсеместно проявленным HT-LP метаморфизмом. Для зерен циркона этого этапа магматизма характерны пиковые значения возраста около 325-340 млн лет и доминирование отрицательных $\varepsilon_{\text {нf }}$ Этапы магматизма II (315-270 млн лет) и III (270-200 млн лет) соотносятся с функционированием вулканического надсубдукционного пояса Скифско-Понтидской дуги. Для зерен циркона этих этапов магматизма характерен разброс величин $\varepsilon_{\mathrm{Hf}}$ от слабоотрицательных до существенно положительных (характерных для деплетированной мантии), что типично для вулканических дуг. Нечеткое разделение II и III этапов магматизма и сильная вариабельность в изученных пробах пиковых значений возраста зерен циркона, которые мы связываем с этими этапами, могут быть обусловлены как изменениями магматической активности в различных сегментах пояса, так и изменениями интенсивности эрозии кристаллических комплексов пояса на последующих этапах эволюции, вызванных тектоническими перестройками внутри океана Палеотетис и его периокеанических структур.
\end{abstract}

КЛЮЧЕВЫЕ СЛОВА: Горный Крым; юрские грубообломочные толщи; детритовые цирконы; U-Pb датирование; Hf изотопная систематика; элементы-примеси; каменноугольно-триасовый период магматической активности; Причерноморье

ФИНАНСИРОВАНИЕ: Работа выполнена в соответствии с планами исследований по темам госзаданий ИФЗ РАН и ГИН РАН, изотопные анализы и их обработка выполнены за счет средств РФФИ (проект № 19-05-00284).

\section{1. ВВЕДЕНИЕ}

Горный Крым (ГК) - часть современного АльпийскоГималайского коллизионного пояса, который образовался и продолжает развиваться в результате столкновения аркт-лавразийских и гондванских континентальных масс. В ГК (рис. 1) выделены киммерийский (киммериды) и син-альпийский (альпиды) структурные комплексы [Mileev et al., 2006, 2009]. Син-альпийский структурный комплекс состоит из залегающих моноклинально меловых и кайнозойских толщ. Киммерийский структурный комплекс сложен неравномерно дислоцированными, преимущественно слоистыми (стратифицированными) образованиями, охватывающими стратиграфический интервал от верхнего триаса до пограничных уровней юры и мела включительно.

В геологическом строении киммерийского структурного комплекса ГК (киммерид ГК) значительную роль играют мощные средне- и верхнеюрские толщи 
грубообломочных пород, представленных в основном галечными и валунными полимиктовыми конгломератами, которые содержат гальки осадочных (преимущественно карбонатных), метаморфических и магматических пород, а также карбонатно-обломочными конгломератами и конглобрекчиями, в том числе валунными. Палеогеографические и палеотектонические обстановки формирования всех этих грубообломочных толщ - предмет длительных дискуссий, которые не завершены до сих пор. Одним из главных предметов этих дискуссий являются источники сноса полимиктового силикокластического обломочного материала в осадочный бассейн, реликты выполнения которого в настоящее время представлены средне- и верхнеюрскими грубообломочными толщами ГК.

Активно внедряемый в практику геологических исследований в последние годы метод изучения зерен детритового циркона $(\mathrm{dZr})$ из обломочных пород (преимущественно песчаников и песчаного матрикса конгломератов, далее будем называть их - песчанистые породы), участвующих в строении разрезов осадочных толщ, позволяет получать новую надежную информацию о U-Pb изотопном возрасте первичных источников зерен dZr, которыми служат кристаллические

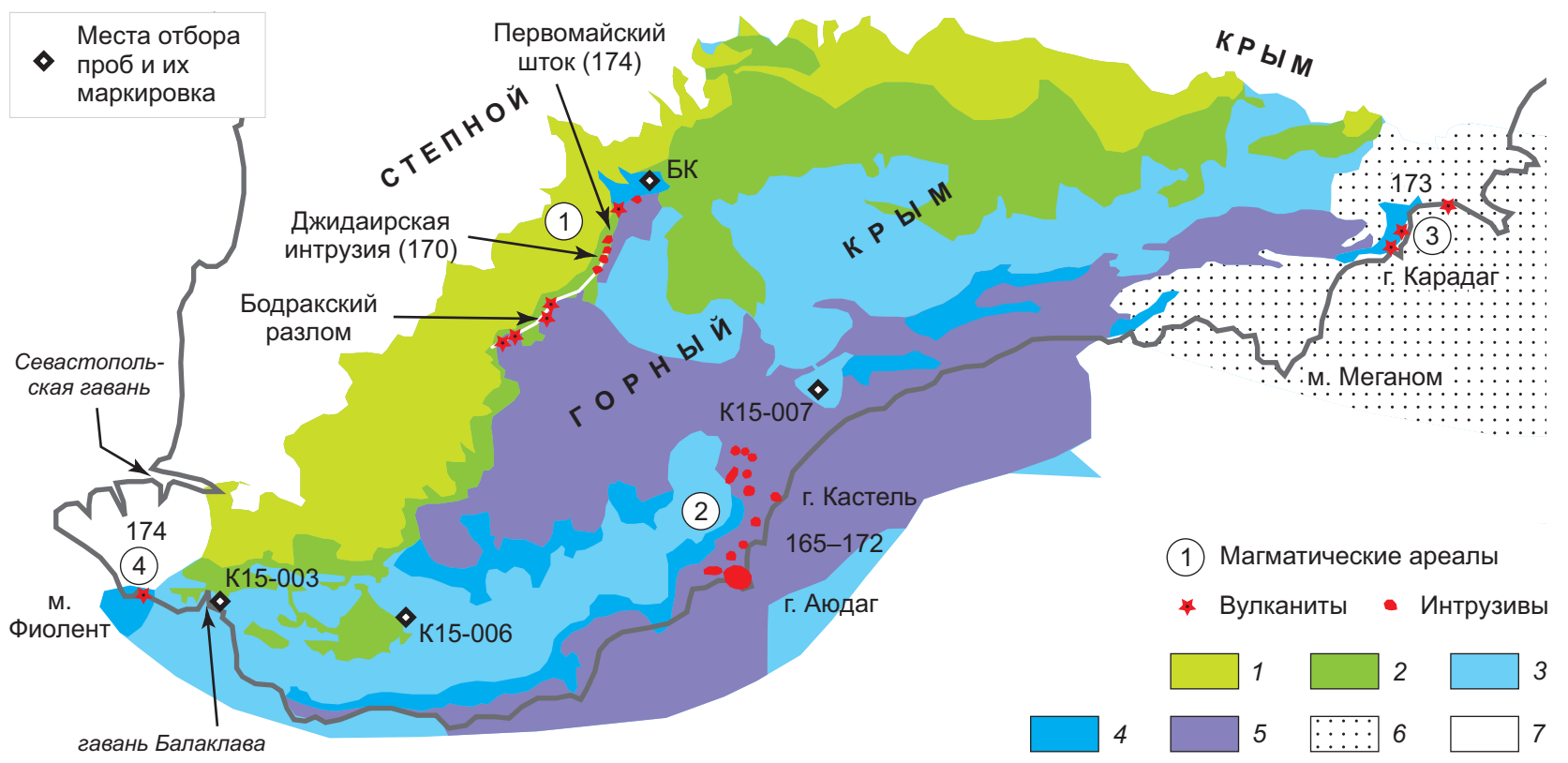

Рис. 1. Геологическая схема Горного Крыма по [Nikishin et al., 2015b] с упрощениями, добавлениями и положением мест отбора проб (БК - битакские конгломераты).

Цифры - возраст в млн лет. 1 - мелководно-морские отложения (верхний мел - эоцен); 2 - отложения шельфа и континентального склона (нижний мел); 3 - отложения шельфа (келловей - берриас); 4 - вулканогенно-осадочные отложения, моласса, шельфовые отложения (средняя юра); 5 - таврическая и эскиординская серии (верхний триас - нижняя юра); 6 - троговые и шельфовые отложения (келловей - неоген); 7 - деформированные шельфовые осадки (келловей - эоцен).

Магматические ареалы: 1 - тела габброидов, диабазов, габбро-диабазов, габбро-диоритов, микродиоритов и долеритов (включая Первомайский шток и Джидаирскую интрузию, для которых получен возраст 174 и 170 млн лет соответственно, U-Pb датировки по циркону, SHRIMP-II [Morozova et al., 2017]), распространенные в окрестностях села Трудолюбовка; 2 - массивы гранитоидов, слагающих горы Аюдаг и Кастель, возраст по регионально-геологическим данным - бат-байос (165-172 млн лет) [Spiridonov et al., 1990; Soloviev, Rogov, 2010; Fikolina et al., 2019; и мн. др.]; 3 - базальты, андезиты, дациты и риолиты, слагающие часть горного массива Карадаг (вулканические постройки Хоба-Тепе и Святая Гора), Ar-Ar возраст вулканитов 173 млн лет [Popov et al., 2019]; 4 - серпентиниты, базальты, долериты и плагиориолиты района Гераклея (мыс Фиолент), для последних получен K-Ar возраст 174 млн лет, метод [Promyslova et al., 2016].

Fig. 1. Schematic geological map of the Mountaineous Crimea (simplified after [Nikishin et al., 2015b]) showing the locations of sampling sites (БК - Bitak conglomerates).

Numbers - age (Ma). 1 - shallow-marine sediments (Upper Cretaceous - Eocene); 2 - shelf and continental slope deposits (Lower Cretaceous); 3 - shelf deposits (Callovian - Berriasian); 4 - Middle Jurassic complexes (volcanic-sedimentary deposits, molasses, and shelf deposits); 5 - Tauride and Eski-Orda groups (Upper Triassic - Lower Jurassic); 6 - trough and shelf deposits (Callovian Neogene); 7 - deformed shelf sediments (Callovian - Eocene).

Magmatic areas: 1 - gabbroids, diabases, gabbro-diabases, gabbro-diorites, micro-diorites and dolerites (including Pervomaiskiy stock and Dzhidair intrusion, 174 and $170 \mathrm{Ma}$, respectively, U-Pb zircon dating, SHRIMP-II), common in the vicinity of Trudolyubovka village [Morozova et al., 2017]; 2 - Granitoids composing Ayudag and Kastel mountains; Bathonian-Bajocian (165-172 Ma), according to the regional geological data (e.g. [Spiridonov et al., 1990; Soloviev, Rogov, 2010; Fikolina et al., 2019]); 3 - basalts, andesites, dacites and rhyolites composing a part of the Karadag Mountains (volcanic structures of Khoba-Tepe and Svyataya-Gora), the Ar-Ar age of the volcanic rocks - $173 \mathrm{Ma}$ is obtained for the volcanic rocks of Karadag [Popov et al., 2019]; 4 - serpentinites, basalts, dolerites and plagioriolites (174 Ma, K-Ar method [Promyslova et al., 2016]) of the Heraclea region (Cape Fiolent). 
комплексы различного (магматического, метаморфического, гидротермального и др.) происхождения. В сочетании с другими геологическими, стратиграфическими, геохронологическими и изотопно-геохимическими данными это позволяет определять/уточнять источники сноса вещества для изучаемых толщ и палеогеографическое/палеотектоническое положение этих источников. Сопоставление наборов значений возраста зерен dZr из разных толщ дает возможность проследить эволюцию питающих провинций в пространстве и во времени, а также может существенно дополнить палеогеографические реконструкции бассейна и палеотектонические реконструкции Черноморско-Балканско-Анатолийско-Кавказского региона (ЧЕБАК региона).

Предыдущими работами по изучению зерен dZr из песчанистых пород средне- и верхнеюрских грубообломочных толщ ГК были охарактеризованы три объекта: среднеюрские битакские конгломераты, распространенные на восточной окраине с. Строгановка в южном пригороде Симферополя; верхнеюрские конгломераты горы Южная Демерджи к северо-востоку от г. Алушты; верхнеюрские конгломераты горы Спилия, расположенной к востоку от Балаклавской бухты. Для битакских конгломератов выполнено U-Pb датирование зерен $\mathrm{dZr}$ [Nikishin et al., 2016]. В работах [Rud'ko et al., 2019; Kuznetsov et al., 2019] приведены результаты комплексного изучения зерен $\mathrm{dZr}$ (U-Pb датирование, Hf-изотопия и содержания элементов-примесей) из конгломератов г. Южная Демерджи (проба К15-007) и г. Спилия (проба К15003). В настоящей статье мы представляем результаты $\mathrm{U}-\mathrm{Pb}$ датирования зерен dZr из толщи верхнеюрских грубообломочных пород, слагающих западный склон г. Биюк-Синор на южном борту Байдарской котловины (БК), около села Орлиное (проба К15-006).

\section{2. РЕЗУЛЬТАТЫ ИЗУЧЕНИЯ ДЕТРИТОВЫХ ЦИРКОНОВ ИЗ ЮРСКИХ ГРУБООБЛОМОЧНЫХ ПОРОД, СЛАГАЮЩИХ ВОСТОЧНЫЙ БОРТ БАЙДАРСКОЙ КОТЛОВИНЫ ОКОЛО СЕЛА ОРЛИНОЕ (ПРОБА К15-006), ГОРНЫЙ КРЫМ}

2.1. Отбор пробы, метод исследования

Общие сведения о геологическом строении БК и положение в разрезе верхнеюрских грубообломочных пород описаны в недавних публикациях [Rud'ko et al., 2017, 2018; Rud'ko, 2018]. Проба К15-006 отобрана на западном склоне г. Биюк-Синор (к югу от с. Орлиное, в юж-

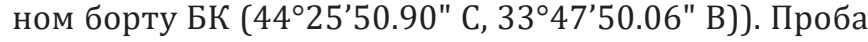
взята из слоя косослоистых песчаников с карбонатным цементом (рис. 2), в 150 м от подошвы разреза верхнеюрских карбонатных брекчий. Подробное описание разреза верхнеюрских отложений приведено в работе [Rud'ko, 2018].

$\mathrm{U}-\mathrm{Pb}$ изотопное датирование зерен dZr методом массспектрометрии с индуктивно связанной плазмой с лазерной абляцией (LA-ICP-MS) выполнено в лаборатории химико-аналитических исследований ГИН РАН. Для лазерного отбора пробы использовалась система лазерной абляции NWR-213 (Electro Scientific Ind.), coвмещенная с магнитосекторным ИСП масс-спектрометром высокого разрешения Element2 (Thermo Scientific Inc.). Технические детали подготовки аналитических препаратов и параметры аппаратуры можно найти в работе [Nikishin et al., 2020].

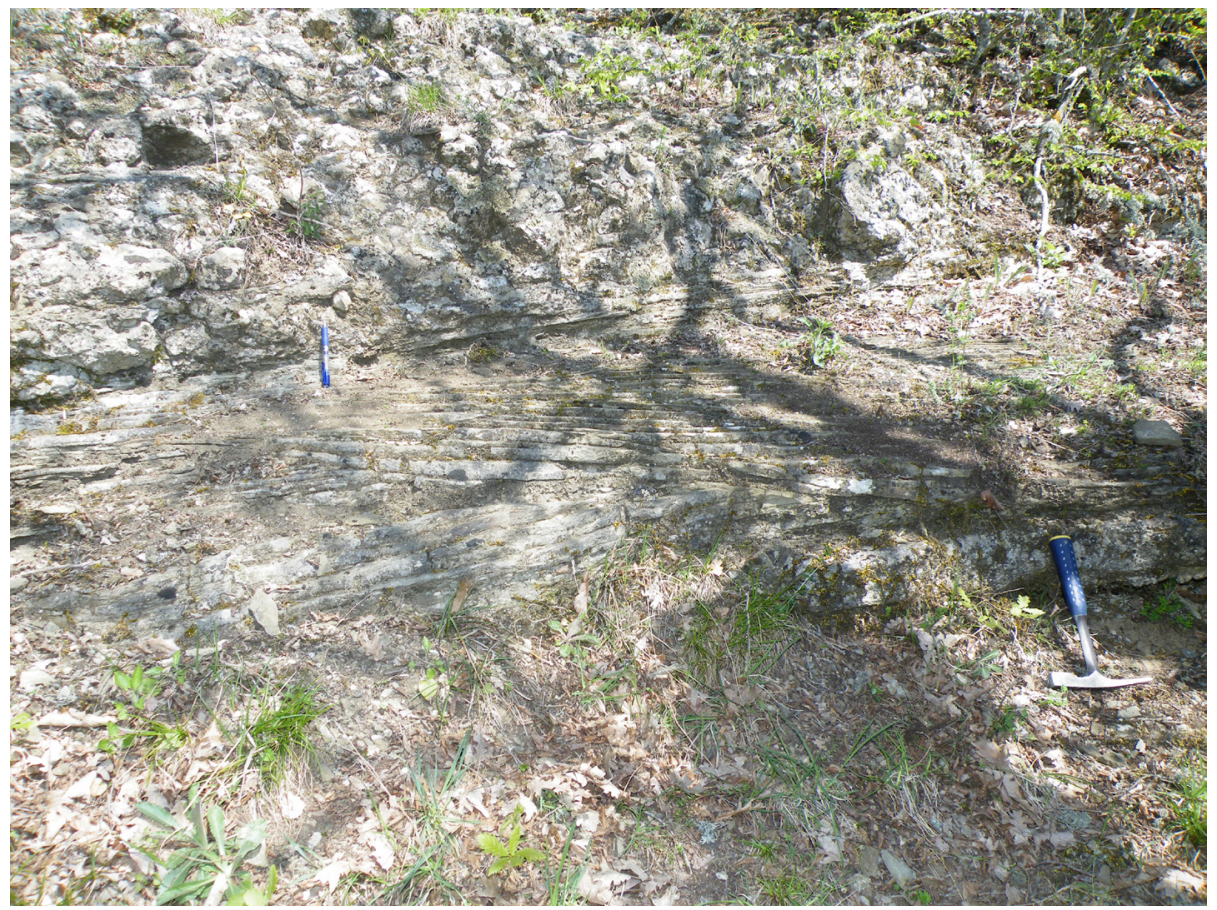

Рис. 2. Фотография косослоистых песчаников с карбонатным цементом, из которых отобрана проба К15-006.

Fig. 2. Photograph of cross-bedded sandstones with carbonate cement (sample K15-006). 
Калибровка изотопных измерений была проведена с использованием циркона GJ-1, качество анализа оценивалось путем последовательного измерения неизвестных образцов и контрольных стандартов циркона 91500 и Plesovice. Для них в ходе измерений получены средневзвешенные конкордантные оценки возраста $( \pm 2 \sigma) 600 \pm 4(\mathrm{n}=52), 1073 \pm 19(\mathrm{n}=9)$ и $340 \pm 6(\mathrm{n}=6)$ млн лет, что в пределах ошибки измерения согласуется с аттестованными по изотопному отношению ${ }^{206} \mathrm{~Pb} /{ }^{238} \mathrm{U}$ средневзвешенными значениями возраста $601.9 \pm 0.4$ $(\mathrm{n}=7), 1063.5 \pm 0.4(\mathrm{n}=7)$ и $337.2 \pm 0.1(\mathrm{n}=10)$ млн лет, полученными методом CA-ID-TIMS [Horstwood et al., 2016]. Методические приемы и константы, используемые для обработки первичных аналитических данных, приведены в работе [Romanyuk et al., 2018], обработка выполнена с помощью коммерческой программы GLITTER [Griffin et al., 2008], приобретенной ГИН РAH, и программы [Ludwig, 2012], размещенной в свободном доступе.

\section{2. Первичные аналитические данные}

Из пробы К15-006 датировано 100 зерен dZr (табл. 1, рис. 3). Только в двух зернах dZr были обнаружены очень низкие содержания урана (U=4 г/т (№ 31), $U=9$ г/т (№ 54)), а в одном - повышенные (U=4015 г/т (№ 16)). В остальных зернах зафиксированы значения содержания урана от 25 до 767 г/т, что существенно выше порога чувствительности аппаратуры и обеспечивает рутинную высокую точность измерений. В большинстве проанализированных зерен dZr величины торийуранового отношения (Th/U) ограничены диапазоном значений от 0.12 до 1.39 , и только одно зерно показало очень низкое значение Th/U, равное 0.07 (№ 34), а одно - высокое значение Th/U, равное 1.96 (№ 13).

Таблица 1. Результаты U-Pb изотопного (LA-ICP-MS) датирования зерен детритового циркона из верхнеюрских грубообломочных пород, восточный борт Байдарской долины, около с. Орлиное, Горный Крым (проба К15-006)

Table 1. U-Pb isotope (LA-ICP-MS) dating of detrital zircons from Upper Jurassic coarse clastic rocks (eastern wall of the Baydar Valley, near the Orlinoe village, Mountainous Crimea, sample K15-006)

\begin{tabular}{|c|c|c|c|c|c|c|c|c|c|c|c|c|c|c|}
\hline \multirow{2}{*}{$\begin{array}{c}\text { № } \\
\text { П/П }\end{array}$} & \multirow{2}{*}{$\begin{array}{c}\text { Номер } \\
\text { анализа } \\
\text { в пробе } \\
\text { К15-006 }\end{array}$} & \multirow{2}{*}{$\mathrm{Th} / \mathrm{U}$} & \multicolumn{5}{|c|}{ Измеренные отношения } & \multicolumn{6}{|c|}{ Возраст, млн лет } & \multirow{2}{*}{$\mathrm{D}, \%$} \\
\hline & & & ${ }^{207} \mathrm{~Pb} /{ }^{235} \mathrm{U}$ & $1 \sigma$ & ${ }^{206} \mathrm{~Pb} /{ }^{238} \mathrm{U}$ & $1 \sigma$ & RHO & ${ }^{206} \mathrm{~Pb} /{ }^{238} \mathrm{U}$ & $1 \sigma$ & ${ }^{207} \mathrm{~Pb} /{ }^{235} \mathrm{U}$ & $1 \sigma$ & ${ }^{207} \mathrm{~Pb} /{ }^{206} \mathrm{~Pb}$ & $1 \sigma$ & \\
\hline 1 & 01 & 0.64 & 0.33158 & 0.00559 & 0.04757 & 0.00056 & 0.698 & 300 & 3 & 291 & 4 & 221 & 22 & -3.0 \\
\hline 2 & 02 & 1.21 & 10.5414 & 0.14022 & 0.47204 & 0.00538 & 0.857 & 2493 & 24 & 2484 & 12 & 2477 & 12 & -0.6 \\
\hline 3 & 03 & 0.58 & 0.64976 & 0.00986 & 0.08139 & 0.00094 & 0.761 & 504 & 6 & 508 & 6 & 526 & 18 & 0.8 \\
\hline 4 & 04 & 1.65 & 0.79912 & 0.01404 & 0.09642 & 0.00114 & 0.673 & 593 & 7 & 596 & 8 & 608 & 21 & 0.5 \\
\hline 5 & 05 & 0.81 & 3.32699 & 0.04705 & 0.26011 & 0.00299 & 0.813 & 1490 & 15 & 1487 & 11 & 1483 & 15 & -0.5 \\
\hline 6 & 06 & 0.45 & 0.22287 & 0.00380 & 0.03234 & 0.00038 & 0.689 & 205 & 2 & 204 & 3 & 195 & 22 & -0.5 \\
\hline 7 & 07 & 1.99 & 1.53263 & 0.02305 & 0.15398 & 0.00179 & 0.773 & 923 & 10 & 944 & 9 & 992 & 17 & 2.3 \\
\hline 8 & 08 & 1.24 & 0.24259 & 0.00451 & 0.03368 & 0.00040 & 0.639 & 214 & 2 & 221 & 4 & 296 & 24 & 3.3 \\
\hline 9 & 09 & 0.53 & 0.81373 & 0.01286 & 0.09811 & 0.00115 & 0.742 & 603 & 7 & 605 & 7 & 610 & 19 & 0.3 \\
\hline 10 & 10 & 0.74 & 0.35888 & 0.00583 & 0.04672 & 0.00054 & 0.711 & 294 & 3 & 311 & 4 & 441 & 20 & 5.8 \\
\hline 11 & 11 & 0.20 & 0.85143 & 0.01141 & 0.10162 & 0.00116 & 0.852 & 624 & 7 & 625 & 6 & 631 & 16 & 0.2 \\
\hline 12 & 12 & 0.08 & 5.42417 & 0.06966 & 0.3416 & 0.00388 & 0.884 & 1894 & 19 & 1889 & 11 & 1883 & 12 & -0.6 \\
\hline 13 & 13 & 0.09 & 3.45554 & 0.04463 & 0.26425 & 0.00300 & 0.879 & 1512 & 15 & 1517 & 10 & 1525 & 13 & 0.9 \\
\hline 14 & 14 & 0.70 & 4.67855 & 0.16328 & 0.31673 & 0.00280 & 0.253 & 1774 & 14 & 1763 & 29 & 1751 & 31 & -1.3 \\
\hline 15 & 15 & 0.42 & 0.57026 & 0.00930 & 0.07296 & 0.00085 & 0.714 & 454 & 5 & 458 & 6 & 479 & 20 & 0.9 \\
\hline 16 & 16 & 0.47 & 0.50163 & 0.00849 & 0.06474 & 0.00076 & 0.694 & 404 & 5 & 413 & 6 & 460 & 21 & 2.2 \\
\hline 17 & 17 & 0.49 & 0.3984 & 0.00908 & 0.04901 & 0.00060 & 0.537 & 308 & 4 & 340 & 7 & 566 & 28 & 10.4 \\
\hline 18 & 18 & 0.58 & 0.429 & 0.00682 & 0.0506 & 0.00059 & 0.733 & 318 & 4 & 362 & 5 & 657 & 19 & 13.8 \\
\hline 19 & 19 & 0.32 & 5.84179 & 0.08388 & 0.35235 & 0.00407 & 0.804 & 1946 & 19 & 1953 & 12 & 1960 & 14 & 0.7 \\
\hline 20 & 20 & 1.12 & 0.49424 & 0.01135 & 0.063 & 0.00076 & 0.525 & 394 & 5 & 408 & 8 & 488 & 29 & 3.6 \\
\hline 21 & 21 & 1.23 & 10.91726 & 0.13689 & 0.47602 & 0.00544 & 0.911 & 2510 & 24 & 2516 & 12 & $\underline{2521}$ & 11 & 0.4 \\
\hline 22 & 22 & 3.17 & 5.94149 & 0.07090 & 0.32359 & 0.00365 & 0.945 & 1807 & 18 & 1967 & 10 & 2140 & 11 & 18.4 \\
\hline 23 & 23 & 0.53 & 0.35402 & 0.00532 & 0.04777 & 0.00055 & 0.766 & 301 & 3 & 308 & 4 & 361 & 19 & 2.3 \\
\hline 24 & 24 & 0.55 & 1.28509 & 0.01813 & 0.13933 & 0.00159 & 0.809 & 841 & 9 & 839 & 8 & 835 & 16 & -0.2 \\
\hline
\end{tabular}


Таблица 1 (продолжение)

Table 1. (continued)

\begin{tabular}{|c|c|c|c|c|c|c|c|c|c|c|c|c|c|c|}
\hline \multirow{2}{*}{$\begin{array}{c}\text { № } \\
\text { П/П }\end{array}$} & \multirow{2}{*}{$\begin{array}{c}\text { Номер } \\
\text { анализа } \\
\text { в пробе } \\
\text { К15-006 }\end{array}$} & \multirow{2}{*}{$\mathrm{Th} / \mathrm{U}$} & \multicolumn{5}{|c|}{ Измеренные отношения } & \multicolumn{6}{|c|}{ Возраст, млн лет } & \multirow{2}{*}{$\mathrm{D}, \%$} \\
\hline & & & ${ }^{207} \mathrm{~Pb} /{ }^{235} \mathrm{U}$ & $1 \sigma$ & ${ }^{206} \mathrm{~Pb} /{ }^{238} \mathrm{U}$ & $1 \sigma$ & RHO & ${ }^{206} \mathrm{~Pb} /{ }^{238} \mathrm{U}$ & $1 \sigma$ & ${ }^{207} \mathrm{~Pb} /{ }^{235} \mathrm{U}$ & $1 \sigma$ & ${ }^{207} \mathrm{~Pb} /{ }^{206} \mathrm{~Pb}$ & $1 \sigma$ & \\
\hline 25 & 25 & 0.21 & 0.29567 & 0.00454 & 0.04102 & 0.00047 & 0.746 & 259 & 3 & 263 & 4 & 298 & 19 & 1.5 \\
\hline 26 & 26 & 0.73 & 0.57686 & 0.00916 & 0.07604 & 0.00088 & 0.729 & 472 & 5 & 462 & 6 & 413 & 20 & -2.1 \\
\hline 27 & 28 & 1.32 & 6.42191 & 0.08060 & 0.37217 & 0.00423 & 0.906 & 2040 & 20 & 2035 & 11 & 2031 & 12 & -0.4 \\
\hline 28 & 29 & 0.34 & 11.04216 & 0.13312 & 0.44439 & 0.00503 & 0.939 & 2370 & 22 & 2527 & 11 & 2655 & 11 & 12.0 \\
\hline 29 & 30 & 0.20 & 1.53494 & 0.01314 & 0.12378 & 0.00072 & 0.679 & 752 & 4 & 944 & 5 & 1424 & 12 & 25.5 \\
\hline 30 & 31 & 0.57 & 0.5955 & 0.00551 & 0.07163 & 0.00042 & 0.634 & 446 & 3 & 474 & 4 & 614 & 15 & 6.3 \\
\hline 31 & 32 & 0.83 & 0.19381 & 0.00236 & 0.03084 & 0.00019 & 0.506 & 196 & 1 & 180 & 2 & -24 & 16 & -8.2 \\
\hline 32 & 33 & 0.67 & 5.88535 & 0.05346 & 0.24538 & 0.00145 & 0.651 & 1415 & 8 & 1959 & 8 & 2596 & 11 & 83.5 \\
\hline 33 & 34 & 1.63 & 0.09592 & 0.00182 & 0.01538 & 0.00011 & 0.377 & 98.4 & 0.7 & 93 & 2 & -7 & 21 & -5.5 \\
\hline 34 & 35 & 0.89 & 2.47434 & 0.02631 & 0.17443 & 0.00109 & 0.588 & 1036 & 6 & 1265 & 8 & 1677 & 14 & 61.9 \\
\hline 35 & 36 & 2.03 & 0.10975 & 0.00183 & 0.01826 & 0.00012 & 0.394 & 116.6 & 0.8 & 106 & 2 & -92 & 25 & -9.1 \\
\hline 36 & 37 & 2.05 & 0.10693 & 0.00175 & 0.01812 & 0.00012 & 0.405 & 115.8 & 0.8 & 103 & 2 & -133 & 24 & -11.1 \\
\hline 37 & 38 & 0.80 & 0.54134 & 0.00703 & 0.06786 & 0.00044 & 0.499 & 423 & 3 & 439 & 5 & 525 & 20 & 3.8 \\
\hline 38 & 39 & 1.78 & 2.12208 & 0.02496 & 0.16245 & 0.00102 & 0.534 & 970 & 6 & 1156 & 8 & 1523 & 15 & 57.0 \\
\hline 39 & 40 & 0.51 & 6.03141 & 0.08026 & 0.36037 & 0.00412 & 0.859 & 1984 & 20 & 1980 & 12 & 1977 & 13 & -0.4 \\
\hline 40 & 41 & 1.08 & 2.1902 & 0.02769 & 0.17258 & 0.00194 & 0.889 & 1026 & 11 & 1178 & 9 & 1469 & 13 & 43.2 \\
\hline 41 & 42 & 1.08 & 0.74479 & 0.00983 & 0.09215 & 0.00104 & 0.855 & 568 & 6 & 565 & 6 & 553 & 16 & -0.5 \\
\hline 42 & 43 & 1.29 & 0.39948 & 0.00603 & 0.05306 & 0.00061 & 0.762 & 333 & 4 & 341 & 4 & 397 & 19 & 2.4 \\
\hline 43 & 44 & 1.26 & 3.3465 & 0.04712 & 0.26197 & 0.00301 & 0.816 & 1500 & 15 & 1492 & 11 & 1481 & 14 & -1.3 \\
\hline 44 & 45 & 0.52 & 0.5197 & 0.00740 & 0.06998 & 0.00080 & 0.803 & 436 & 5 & 425 & 5 & 366 & 17 & -2.5 \\
\hline 45 & 46 & 1.24 & 0.32117 & 0.00563 & 0.04479 & 0.00052 & 0.662 & 282 & 3 & 283 & 4 & 286 & 23 & 0.4 \\
\hline 46 & 48 & 0.71 & 0.7063 & 0.01015 & 0.08918 & 0.00102 & 0.796 & 551 & 6 & 543 & 6 & 509 & 18 & -1.5 \\
\hline 47 & $49 \mathrm{~A}$ & 0.41 & 0.34699 & 0.00528 & 0.04915 & 0.00056 & 0.749 & 309 & 3 & 302 & 4 & 250 & 20 & -2.3 \\
\hline 48 & $49 \mathrm{~B}$ & 0.22 & 0.36658 & 0.00444 & 0.04853 & 0.00033 & 0.561 & 305 & 2 & 317 & 3 & 404 & 14 & 3.9 \\
\hline 49 & $50 \mathrm{~A}$ & 0.81 & 0.50361 & 0.00693 & 0.05231 & 0.00037 & 0.514 & 329 & 2 & 414 & 5 & 923 & 12 & 25.8 \\
\hline 0 & $50 \mathrm{~B}$ & 0.90 & 0.48576 & 0.00605 & 0.05795 & 0.00065 & 0.901 & 363 & 4 & 402 & 4 & 632 & 15 & 10.7 \\
\hline 51 & $51 \mathrm{~A}$ & 1.26 & 0.42226 & 0.00514 & 0.03768 & 0.00042 & 0.916 & 238 & 3 & 358 & 4 & 1228 & 13 & 50.4 \\
\hline 52 & $51 \mathrm{~B}$ & 0.95 & 0.45269 & 0.00591 & 0.04225 & 0.00030 & 0.544 & 267 & 2 & 379 & 4 & 1139 & 10 & 41.9 \\
\hline 53 & 52 & 0.78 & 0.41483 & 0.00955 & 0.05614 & 0.00069 & 0.534 & 352 & 4 & 352 & 7 & 354 & 29 & 0.0 \\
\hline 54 & 53 & 1.20 & 0.37408 & 0.00486 & 0.0513 & 0.00057 & 0.855 & 322 & 3 & 323 & 4 & 324 & 16 & 0.3 \\
\hline 55 & 54 & 0.19 & 0.4031 & 0.00793 & 0.05477 & 0.00065 & 0.603 & 344 & 4 & 344 & 6 & 345 & 25 & 0.0 \\
\hline 56 & 55 & 0.57 & 0.26939 & 0.00532 & 0.03828 & 0.00045 & 0.595 & 242 & 3 & 242 & 4 & 243 & 26 & 0.0 \\
\hline 57 & 56 & 0.50 & 0.35148 & 0.00509 & 0.0486 & 0.00055 & 0.781 & 306 & 3 & 306 & 4 & 306 & 18 & 0.0 \\
\hline 58 & 57 & 1.45 & 0.86085 & 0.01356 & 0.10279 & 0.00118 & 0.729 & 631 & 7 & 631 & 7 & 630 & 19 & 0.0 \\
\hline 59 & 58 & 1.35 & 0.52992 & 0.00849 & 0.06912 & 0.00079 & 0.713 & 431 & 5 & 432 & 6 & 437 & 20 & 0.2 \\
\hline 60 & 59 & 1.02 & 0.52243 & 0.01161 & 0.06512 & 0.00080 & 0.553 & 407 & 5 & 427 & 8 & 537 & 28 & 4.9 \\
\hline 61 & $62 \mathrm{~A}$ & 1.31 & 6.95774 & 0.09961 & 0.3865 & 0.00448 & 0.810 & 2107 & 21 & 2106 & 13 & 2106 & 14 & 0.0 \\
\hline 62 & $62 \mathrm{~B}$ & 0.82 & 0.34727 & 0.00690 & 0.04807 & 0.00057 & 0.597 & 303 & 4 & 303 & 5 & 303 & 26 & 0.0 \\
\hline 63 & $62 \mathrm{Aa}$ & 1.54 & 0.33707 & 0.00632 & 0.04559 & 0.00054 & 0.632 & 287 & 3 & 295 & 5 & 356 & 24 & 2.8 \\
\hline 64 & 63 & 2.26 & 0.54212 & 0.00961 & 0.06674 & 0.00078 & 0.659 & 416 & 5 & 440 & 6 & 564 & 22 & 5.8 \\
\hline 65 & 64 & 0.08 & 5.92579 & 0.08336 & 0.35409 & 0.00402 & 0.807 & 1954 & 19 & 1965 & 12 & 1977 & 14 & 1.2 \\
\hline
\end{tabular}


Таблица 1 (продолжение)

Table 1. (continued)

\begin{tabular}{|c|c|c|c|c|c|c|c|c|c|c|c|c|c|c|}
\hline \multirow{2}{*}{$\begin{array}{c}\text { № } \\
\text { п/П }\end{array}$} & \multirow{2}{*}{$\begin{array}{c}\text { Номер } \\
\text { анализа } \\
\text { в пробе } \\
\text { К15-006 }\end{array}$} & \multirow{2}{*}{$\mathrm{Th} / \mathrm{U}$} & \multicolumn{5}{|c|}{ Измеренные отношения } & \multicolumn{6}{|c|}{ Возраст, млн лет } & \multirow{2}{*}{$\mathrm{D}, \%$} \\
\hline & & & ${ }^{207} \mathrm{~Pb} /{ }^{235} \mathrm{U}$ & $1 \sigma$ & ${ }^{206} \mathrm{~Pb} /{ }^{238} \mathrm{U}$ & $1 \sigma$ & RHO & ${ }^{206} \mathrm{~Pb} /{ }^{238} \mathrm{U}$ & $1 \sigma$ & ${ }^{207} \mathrm{~Pb} /{ }^{235} \mathrm{U}$ & $1 \sigma$ & ${ }^{207} \mathrm{~Pb} /{ }^{206} \mathrm{~Pb}$ & $1 \sigma$ & \\
\hline 66 & 65 & 0.30 & 0.25977 & 0.00314 & 0.02491 & 0.00017 & 0.565 & 159 & 1 & 234 & 3 & 1085 & 12 & 47.2 \\
\hline 67 & 66 & 0.87 & 0.49081 & 0.00919 & 0.06475 & 0.00077 & 0.635 & 404 & 5 & 405 & 6 & 411 & 24 & 0.2 \\
\hline 68 & 67 & 0.52 & 0.33815 & 0.00586 & 0.04475 & 0.00052 & 0.671 & 282 & 3 & 296 & 4 & 404 & 22 & 5.0 \\
\hline 69 & 68 & 0.92 & 0.32234 & 0.01683 & 0.04285 & 0.00070 & 0.313 & 270 & 4 & 284 & 13 & 394 & 70 & 5.2 \\
\hline 70 & $68 \mathrm{~A}$ & 0.55 & 0.34943 & 0.00840 & 0.04824 & 0.00060 & 0.517 & 304 & 4 & 304 & 6 & 309 & 31 & 0.0 \\
\hline 71 & 69 & 0.71 & 0.38716 & 0.00754 & 0.05288 & 0.00062 & 0.602 & 332 & 4 & 332 & 6 & 333 & 25 & 0.0 \\
\hline 72 & 70 & 0.96 & 0.23855 & 0.00652 & 0.03429 & 0.00044 & 0.469 & 217 & 3 & 217 & 5 & 216 & 37 & 0.0 \\
\hline 73 & 71 & 0.54 & 0.2827 & 0.00671 & 0.04002 & 0.00049 & 0.516 & 253 & 3 & 253 & 5 & 251 & 31 & 0.0 \\
\hline 74 & 72 & 1.03 & 4.75867 & 0.07887 & 0.31762 & 0.00375 & 0.712 & 1778 & 18 & 1778 & 14 & 1777 & 17 & -0.1 \\
\hline 75 & 73 & 0.56 & 0.57759 & 0.01065 & 0.07438 & 0.00087 & 0.634 & 462 & 5 & 463 & 7 & 465 & 24 & 0.2 \\
\hline 76 & 74 & 0.60 & 1.45124 & 0.02350 & 0.15171 & 0.00174 & 0.708 & 911 & 10 & 910 & 10 & 910 & 19 & -0.1 \\
\hline 77 & 75 & 0.01 & 0.79389 & 0.01415 & 0.09644 & 0.00113 & 0.657 & 594 & 7 & 593 & 8 & 593 & 23 & -0.2 \\
\hline 8 & 76 & 1.62 & 43.81437 & 9.36699 & 0.44715 & 0.09129 & 0.955 & 2383 & 814 & 3861 & 424 & 4752 & 274 & 99.4 \\
\hline 79 & 77 & 0.05 & 0.55804 & 0.01300 & 0.07174 & 0.00089 & 0.533 & 447 & 10 & 450 & 16 & 469 & 62 & 0.7 \\
\hline 80 & 78 & 0.66 & 0.3523 & 0.00512 & 0.04871 & 0.00055 & 0.777 & 307 & 6 & 306 & 8 & 305 & 36 & -0.3 \\
\hline 81 & 79 & 0.72 & 0.34102 & 0.00636 & 0.04785 & 0.00056 & 0.628 & 301 & 6 & 298 & 10 & 272 & 50 & -1.0 \\
\hline 82 & 80 & 1.14 & 0.7091 & 0.00962 & 0.066 & 0.00075 & 0.838 & 412 & 10 & 544 & 12 & 1145 & 30 & 32.0 \\
\hline 83 & $81 \mathrm{~A}$ & 0.84 & 0.35039 & 0.00556 & 0.04868 & 0.00056 & 0.725 & 306 & 6 & 305 & 8 & 294 & 42 & -0.3 \\
\hline 84 & $81 \mathrm{~B}$ & 0.58 & 0.49174 & 0.00858 & 0.053 & 0.00063 & 0.681 & 333 & 8 & 406 & 12 & 847 & 42 & 21.9 \\
\hline 85 & 82 & 0.79 & 0.27344 & 0.00528 & 0.03986 & 0.00047 & 0.611 & 252 & 6 & 245 & 8 & 184 & 52 & -2.8 \\
\hline 86 & 83 & 1.30 & 1.09927 & 0.01604 & 0.12908 & 0.00148 & 0.786 & 783 & 16 & 753 & 16 & 666 & 34 & -3.8 \\
\hline 87 & 84 & 0.57 & 1.15881 & 0.01952 & 0.13155 & 0.00155 & 0.699 & 797 & 18 & 781 & 18 & 738 & 42 & -2.0 \\
\hline 88 & 85 & 0.54 & 0.30563 & 0.00623 & 0.04375 & 0.00053 & 0.594 & 276 & 6 & 271 & 10 & 226 & 54 & -1.8 \\
\hline 89 & 86 & 1.52 & 0.28884 & 0.00671 & 0.03835 & 0.00048 & 0.539 & 243 & 6 & 258 & 10 & 398 & 62 & 6.2 \\
\hline 90 & 87 & 1.14 & 0.34445 & 0.00500 & 0.03995 & 0.00046 & 0.793 & 253 & 6 & 301 & 8 & 693 & 34 & 19.0 \\
\hline 91 & 88 & 0.48 & 4.82658 & 0.06323 & 0.3215 & 0.00370 & 0.878 & 1797 & 36 & 1790 & 22 & 1781 & 26 & -0.9 \\
\hline 92 & 89 & 0.94 & 0.77313 & 0.01161 & 0.09622 & 0.00112 & 0.775 & 592 & 14 & 582 & 14 & 541 & 38 & -1.7 \\
\hline 93 & 90 & 1.49 & 10.77545 & 0.13842 & 0.47509 & 0.00547 & 0.896 & 2506 & 48 & 2504 & 24 & 2503 & 24 & -0.1 \\
\hline 94 & 91 & 0.68 & 0.29477 & 0.00499 & 0.04241 & 0.00050 & 0.696 & 268 & 6 & 262 & 8 & 215 & 44 & -2.2 \\
\hline 95 & 92 & 0.86 & 0.26034 & 0.00531 & 0.03535 & 0.00043 & 0.596 & 224 & 6 & 235 & 8 & 348 & 52 & 4.9 \\
\hline 96 & 93 & 0.36 & 0.3223 & 0.00568 & 0.04681 & 0.00055 & 0.667 & 295 & 6 & 284 & 8 & 193 & 46 & -3.7 \\
\hline 97 & 94 & 0.80 & 0.2747 & 0.00456 & 0.04078 & 0.00048 & 0.709 & 258 & 6 & 246 & 8 & 142 & 44 & -4.7 \\
\hline 98 & 95 & 0.74 & 0.38019 & 0.00702 & 0.05284 & 0.00063 & 0.646 & 332 & 8 & 327 & 10 & 295 & 50 & -1.5 \\
\hline 99 & 96 & 0.94 & 0.33216 & 0.00525 & 0.047 & 0.00055 & 0.740 & 296 & 6 & 291 & 8 & 253 & 42 & -1.7 \\
\hline 100 & 97 & 0.75 & 0.21719 & 0.00604 & 0.0315 & 0.00040 & 0.457 & $\underline{200}$ & 4 & 200 & 10 & 196 & 74 & 0.0 \\
\hline
\end{tabular}

Примечание. Полужирным шрифтом выделены значения, принятые за возраст циркона (при возрасте <1 млрд лет для вычисления возраста использованы отношения ${ }^{206} \mathrm{~Pb} /{ }^{238} \mathrm{U}$, при возрасте $\geq 1$ млрд лет - отношения $\left.{ }^{207} \mathrm{~Pb} /{ }^{206} \mathrm{~Pb}\right)$. Подчеркнуты - минимальный и максимальный возраст цирконов в пробе. D - дискордантность датировок, вычислялась как $\mathrm{D}=\left(\right.$ Возраст $\left.\left({ }^{207} \mathrm{~Pb} /{ }^{235} \mathrm{U}\right) / \mathrm{Bozpact}\left({ }^{206} \mathrm{~Pb} /{ }^{238} \mathrm{~Pb}\right)-1\right) \cdot 100 \%$ при возрасте циркона $\leq 1 \mathrm{млрд} \mathrm{лет,} \mathrm{D}=\left(\right.$ Возраст $\left({ }^{207} \mathrm{~Pb} /{ }^{206} \mathrm{~Pb}\right) /$ Возраст $\left.\left({ }^{206} \mathrm{~Pb} /{ }^{238} \mathrm{~Pb}\right)-1\right) \cdot 100 \%$ при возрасте циркона >1 млрд лет. Датировки (курсив) со степенью дискордантности $\mathrm{D}>10 \%$ или $\mathrm{D} \leq-5 \%$ или большой аналитической ошибкой не учитывались в гистограммах, КПВ и тесте Колмогорова-Смирнова.

Note. The values accepted for the zircons age are highlighted in bold (ratios ${ }^{206} \mathrm{~Pb} /{ }^{238} \mathrm{U}$ were used to calculate the age for ages $<1 \mathrm{Ga}$, and ratios ${ }^{207} \mathrm{~Pb} /{ }^{206} \mathrm{~Pb}$ for ages $\geq 1 \mathrm{Ga})$. The minimum and maximum ages of zircons in the sample are underlined. $\mathrm{D}-$ discordance of dating, calculated as $\mathrm{D}=\left(\mathrm{Age}\left({ }^{207} \mathrm{~Pb} /{ }^{235} \mathrm{U}\right) /\right.$ Age $\left.\left({ }^{206} \mathrm{~Pb} /{ }^{238} \mathrm{~Pb}\right)-1\right) \cdot 100 \%$, with zircon age $\leq 1 \mathrm{Ga}, \mathrm{D}=\left(\right.$ Age $\left({ }^{207} \mathrm{~Pb} /{ }^{206} \mathrm{~Pb}\right) /$ Age $\left.\left({ }^{206} \mathrm{~Pb} /{ }^{238} \mathrm{~Pb}\right)-1\right) \cdot 100 \%$, with zircon age $>1 \mathrm{Ga}$. Dates (italics) with D>10 \%, or $\mathrm{D} \leq-5 \%$, or a large analytical error were not taken into account in the histograms, PDP and the Kolmogorov-Smirnov test. 
Всего $78 \mathrm{U}-\mathrm{Pb}$ определений возраста зерен dZr оказались кондиционными (т.е. ошибка аналитических измерений обеспечивает точность оценки возраста $<50$ млн лет, коррекция на общий свинец $<50$ млн лет, а дискордантность возрастных характеристик D заключена в диапазоне $-5 \%<\mathrm{D} \leq 10 \%$ ). По этим датировкам построены гистограмма и кривая плотности вероятности $(К П В)$ (рис. 4, а), и только эти датировки использованы далее для теста Колмогорова-Смирнова.

\section{3. АНАЛИЗ РЕЗУЛЬТАТОВ ИЗУЧЕНИЯ ЗЕРЕН ДЕТРИТОВОГО ЦИРКОНА ИЗ ПЕСЧАНИСТЫХ ПОРОД СРЕДНЕ- И ВЕРХНЕЮРСКИХ ГРУБООБЛОМОЧНЫХ ТОЛЩ ГОРНОГО КРЫМА}

Мощные грубообломочные толщи киммерийского структурного комплекса ГК представлены на различных стратиграфических уровнях от тоара до валанжина. Объектом рассмотрения настоящей статьи являются лишь некоторые из этих толщ, попадающие в среднеи верхнеюрский стратиграфический интервал.

Ранее уже были изучены зерна dZr из песчанистых пород толщи битакских конгломератов, верхней толщи конгломератов горы Южная Демерджи и толщи конгломератов горы Спилия. Таким образом, с учетом новых данных, представленных в этой статье, к настоящему времени есть результаты изучения зерен $\mathrm{dZr}$ из песчанистых пород из разрезов средне- и верхнеюрских грубообломочных толщ, распространенных в четырех пространственно разобщенных локациях в ГК (рис. 4). По-видимому, самая молодая из этих четырех толщ - верхняя толща конгломератов горы Южная Демерджи (ее возраст ограничен снизу рубежом поздний кимеридж по значению возраста группы из пяти самых


2018]). Самая древняя - толща битакских конгломератов (ее возраст на основании биостратиграфических данных соответствует средней юре [Nikishin et al., 2016, и ссылки в данной работе]). Конгломераты горы Спилия у Балаклавы и конглобрекчии горы Биюк-Синор на южном борту Байдарской котловины у с. Орлиное либо занимают промежуточное стратиграфическое положение, либо близки по возрасту толще горы Южная Демерджи [Rud'ko et al., 2017].

\section{1. Сопоставление результатов U-Pb датирования зерен детритового циркона из песчанистых пород средне- и верхнеюрских грубообломочных толщ Горного Крыма}

Визуальное сопоставление кривых плотности вероятности (КПВ), иллюстрирующих характер распределения $\mathrm{U}-\mathrm{Pb}$ изотопных возрастов dZr из всех четырех изученных объектов средне- и верхнеюрских грубообломочных толщ ГК (рис. 4), показало, что эти КПВ во многом сходны. Прежде всего это выражается в том, что во всех четырех случаях число датировок, попадающих в каменноугольно-триасовый возрастной интервал, в разы превосходит число датировок других возрастных групп и всегда больше половины от общего числа датировок.

Временной интервал неопротерозой - девон представлен меньшим числом датировок dZr. Эти датировки, несмотря на их немногочисленность, формируют небольшие группы. В некоторых случаях для этих групп на КПВ проявлены пики, совпадающие для всех четырех

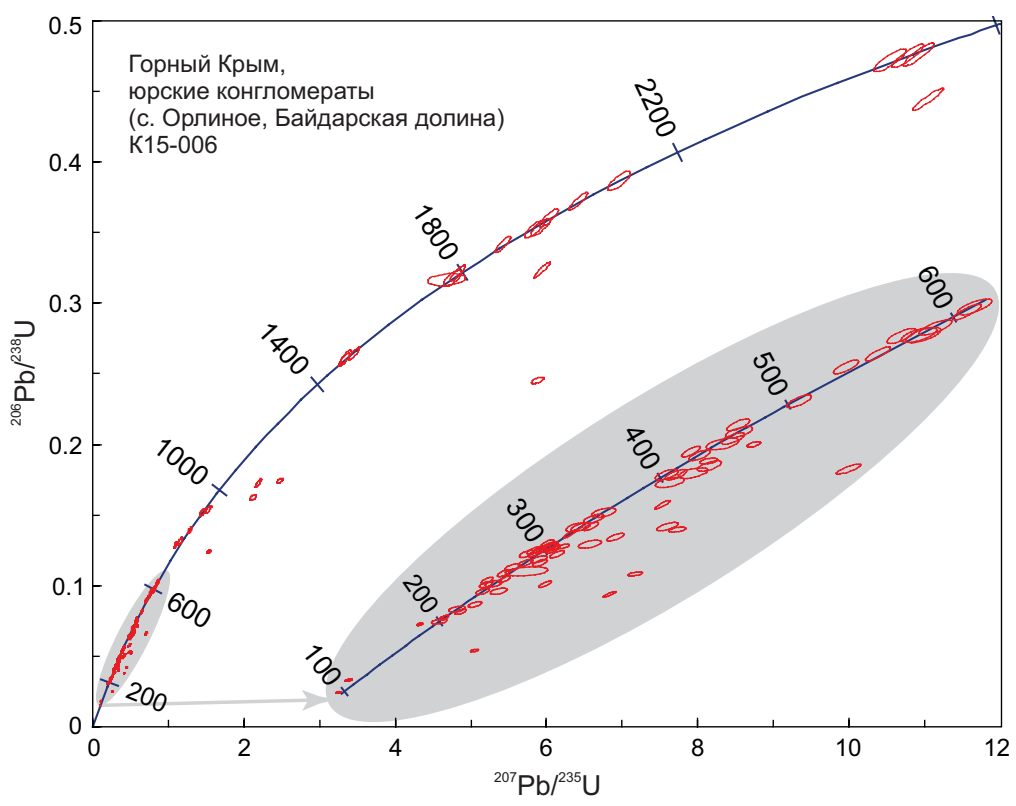

Рис. 3. Диаграмма с конкордией, иллюстрирующая результаты изучения U-Pb изотопной системы проанализированных зерен dZr из пробы К15-006. Эллипсы показывают 68\%-ный доверительный интервал. На серой врезке - увеличенный фрагмент конкордии для интервала от 100 до 600 млн лет.

Fig. 3. Concordia diagram illustrating the study results for the U-Pb isotope system of the analyzed dZr grains from sample K15-006. Ellipses show a 68\% confidence interval. Gray insert - zoomed-in fragment of the concordia for the age interval from 100 to $600 \mathrm{Ma}$. 


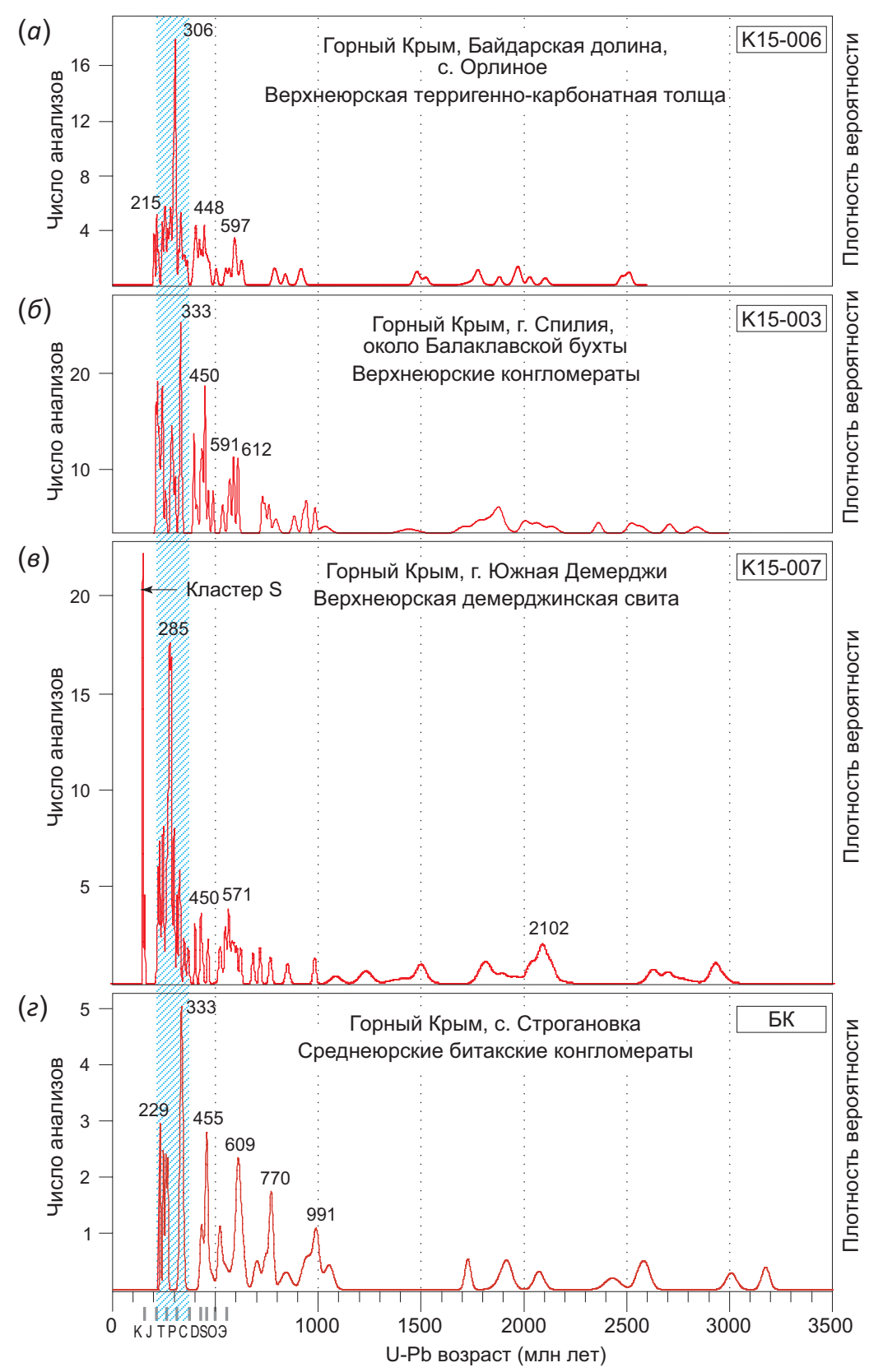

Рис. 4. Сопоставление КПВ, иллюстрирующих характер распределения U-Pb изотопных возрастов dZr из песчанистых пород средне- и верхнеюрских грубообломочных толщ Горного Крыма.

Поле с голубой косой штриховкой маркирует каменноугольно-триасовый этап магматической активности. Положение мест отбора проб К15-003, К15-007, К15-006 и БК см. на рис. 1.

$(a)$ - песчанистые породы из верхнеюрской толщи конгломератобрекчий на западном склоне г. Биюк-Синор на юге Байдарской котловины, около села Орлиное (проба К15-006, n=78), (б) - песчанистые породы из верхнеюрских конгломератов г. Спилия, около Балаклавской бухты (проба К15-003, n=67), (в) - песчанистые породы из верхнеюрских конгломератов г. Южная Демерджи (проба К15-007, n=87), (2) - песчанистые породы из толщи среднеюрских битакских конгломератов (проба БК, исходные данные по [Nikishin et al., 2016], анализы с D>10 \% не учитывались, n=39). Источники данных: $(a)$ - настоящая работа; $(6,8)$ - [Kuznetsov et al., 2019]; (2) - [Nikishin et al., 2016].

Fig. 4. Comparison of PDP illustrating the distribution of U-Pb isotopic ages of dZr from sandy rocks of the Middle and Upper Jurassic coarse clastic strata of the Mountainous Crimea.

A bar with blue oblique hatching marks the Carbon-Triassic stage of magmatic activity. See Fig. 1 for the locations of sampling sites K15-003, K15-007, K15-006 and БК.

(a) - sandy rocks from the Upper Jurassic stratum of conglomerate-breccias on the western slope of Biyuk-Sinor Mnt. in the southern wall of the Baidar basin, near Orlinoye village (sample K15-006, n=78), (б) - sandy rocks from the Upper Jurassic conglomerates of the Spilia Mnt. near Balaklava Harbor (sample K15-003, n=67), ( 8 - sandy rocks from the Upper Jurassic conglomerates of the Southern Demerdzhi Mnt. (sample K15-007, n=87), (2) - sandy rocks from the Middle Jurassic Bitak conglomerates (БК sample, initial data according to [Nikishin et al., 2016], analyzes with D>10\% were not taken into account, $\mathrm{n}=39)$. Data sources: $(a)-$ the present article; (б, в) - [Kuznetsov et al., 2019]; (2) - [Nikishin et al., 2016]. 
проб, например пики около значений 600 млн лет и в интервале 455-434 млн лет.

Во временной интервал архей - мезопротерозой попадают только единичные, немногочисленные датировки dZr. Это свидетельствует о том, что зерна dZr c архейско-мезопротерозойским возрастом были рециклированы, и возможно неоднократно, а не напрямую попали из разрушавшихся кристаллических пород в средне- и верхнеюрские грубообломочные толщи ГК.

В целом хорошая схожесть КПВ возрастов зерен $\mathrm{dZr}$ из песчанистых пород средне- и верхнеюрских грубообломочных толщ ГК находит количественное подтверждение с помощью теста Колмогорова-Смирнова (КСтеста). Этот тест применяется для того, чтобы определить, подчиняются ли два эмпирических распределения

Таблица 2. Величины взаимных парных коэффициентов $p$ теста Колмогорова-Смирнова для наборов возрастов зерен детритового циркона из грубообломочных юрских пород Горного Крыма

Table 2. Mutual paired coefficients $p$ of the Kolmogorov-Smirnov test for the sets of ages of detrital zircons from coarse Jurassic rocks of the Mountainous Crimea

\begin{tabular}{|c|c|c|c|c|}
\hline & K15-007 & K15-003 & K15-006 & БК \\
\hline $\begin{array}{l}\text { К15-007 (Демерджи/ } \\
\text { Demerdzhi) }\end{array}$ & & 0.331 & 0.222 & 0.057 \\
\hline $\begin{array}{l}\text { K15-003 (Спилия/ } \\
\text { Spilia) }\end{array}$ & 0.331 & & 0.191 & 0.685 \\
\hline $\begin{array}{l}\text { K15-006 (Орлиное/ } \\
\text { Orlinoe) }\end{array}$ & 0.222 & 0.191 & & 0.015 \\
\hline БК (Битак/Bitak) & 0.057 & 0.685 & 0.015 & \\
\hline
\end{tabular}

Примечание. Расчеты выполнены с помощью программы [Guynn, Gehrels, 2010], размещенной в свободном доступе. Полужирным шрифтом выделены значения $p$ больше принятого порогового 0.05 . Места отбора проб см. рис. 1.

Note. The calculations were performed using the free-access program [Guynn, Gehrels, 2010]. The p-values above the accepted threshold value of 0.05 are highlighted in bold. Sampling locations are shown in Fig. 1. одному закону. Обычно стандартный уровень значимости КС-теста принимается равным 95 \%, то есть если величина вычисляемого коэффициента $p$ превышает пороговое значение 0.05 , то сравниваемые эмпирические распределения сходны и подчиняются одному закону с вероятностью $95 \%$.

Все взаимные парные коэффициенты $p$ тестируемых наборов возрастов dZr из проб К15-003, K15-007, K15-006 и БК, за исключением одного, показали величины $p$ выше порогового (табл. 2 и рис. 5). Взаимный коэффициент $p=0.015$ ниже порогового получился только для пары БК и К15-006.

Главным отличием между всеми четырьмя сравниваемыми наборами возрастов dZr является наличие в песчанистых породах из верхней толщи конгломератов г. Южная Демерджи группы очень молодых, фактически одновозрастных, зерен dZr (кластер S), которые интерпретированы как зерна циркона, произошедшие из локального источника [Kuznetsov et al., 2019]. Других юрских зерен dZr ни в одной из четырех изученных к настоящему времени проб, отобранных из песчанистых пород средне- и верхнеюрских грубообломочных толщ ГК, не зафиксировано. Также можно отметить отсутствие во всех пробах, кроме пробы К15-007, мезопротерозойских зерен $\mathrm{dZr}$.

\section{2. Сопоставление и интерпретация величин Th/U \\ в датированных зернах детритового циркона из песчанистых пород средне- и верхнеюрских грубообломочных толщ}

Отношение весовых количеств тория и урана (Th/U) в цирконе большинства магматических пород (т.е. в цирконе магматического происхождения) варьируется от 0.1 до 1.0 (см. обзор [Kirkland et al., 2015]). Низкие значения Th/U принято считать статистически свойственными кристаллам циркона метаморфического происхождения. Однако по величине «порогового» значения Th/U до сих пор нет консенсуса: в разных работах

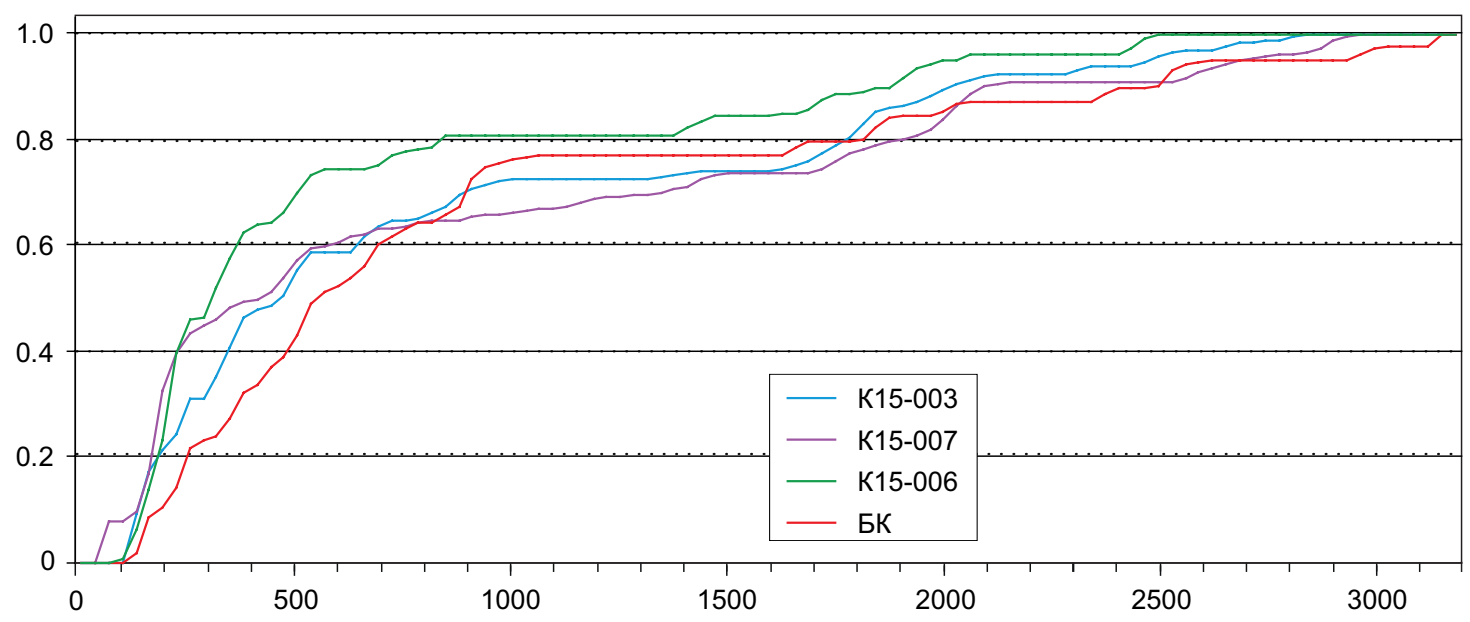

Рис. 5. Кумулятивные кривые для U-Pb изотопных возрастов dZr из песчанистых пород средне- и верхнеюрских грубообломочных толщ Горного Крыма. См. подпись к рис. 4.

Fig. 5. Cumulative curves for U-Pb isotopic ages of dZr from sandy rocks of the Middle and Upper Jurassic coarse clastic strata of the Crimean Mountains. See the caption of Fig. 4. 
предлагаются «пороговые» величины этого отношения от 0.5 до 0.1: в [Kirkland et al., 2015] - 0.5, в [Hoskin, Schaltegger, 2003] - 0.2, в [Teipel et al., 2004] - 0.1.

Высокие величины Th/U>1.5, наряду с другими характеристиками, статистически присущи циркону из мафических магматических пород [Kaczmarek et al., 2008; Linnemann et al., 2011]. Нельзя при этом не отметить, что циркон с высокими значениями $\mathrm{Th} / \mathrm{U}$ иногда может быть сформирован в обстановках метаморфизма высоких степеней [Wanless et al., 2011]. Для циркона, кристаллизовавшегося в гранитах при низких температурах, характерны более высокие содержания U и пониженные Th, что в результате приводит и к пониженным величинам Th/U в низкотемпературных кристаллах [Harrison et al., 2007].

Большинство изученных зерен dZr из песчанистых пород средне- и верхнеюрских грубообломочных толщ ГК показали величины Th/U в пределах от 0.2 до 1.0 (рис. 6). Эти значения считаются статистически присущими магматогенному циркону из магматических пород кремнекислого и среднего состава. Источниками зерен dZr с такими значениями Th/U, наиболее вероятно, были обычные интрузивные гранитоидные комплексы нормальной или пониженной кремнекислотности или их вулканические эквиваленты. Все же немногочисленные зерна dZr показали величины Th/U более
1.0 и единичные - даже более 1.5 , а для пяти зерен, напротив, зафиксированы очень низкие торий-урановые отношения (Th/U<<0.1). Это означает, что среди первичных источников этих зерен dZr могли быть специфические и/или редко встречающиеся комплексы. Первичными источниками зерен dZr с повышенными величинами Th/U могли быть комплексы, в которых широким распространением пользовались мафические породы (например, офиолитовые ассоциации, базитовые интрузии и т.п.) и/или породы, подвергшиеся высокотемпературному метаморфизму (например, гранулитовые комплексы). Зерна dZr с пониженными значениями Th/U, скорее всего, имеют метаморфическое происхождение. Они могли иметь своими первичными источниками (ультра)высокобарические комплексы (эклогиты) или, например, такие «экзотические» комплексы, как ультранизкотемпературные гранитоиды.

Сопоставление величин Th/U зерен dZr в пробах БК, К15-006, К15-003, К15-007 не выявило каких-либо ярких различий между пробами. Можно только отметить, что среди зерен dZr каменноугольно-триасового (период магматической активности в Причерноморье) возраста из песчанистых пород толщи среднеюрских битакских конгломератов не зафиксировано ни одного $\mathrm{dZr}$ с Th/U>0.8, т.е. среди первичных источников этих зерен dZr маловероятны мафические породы.

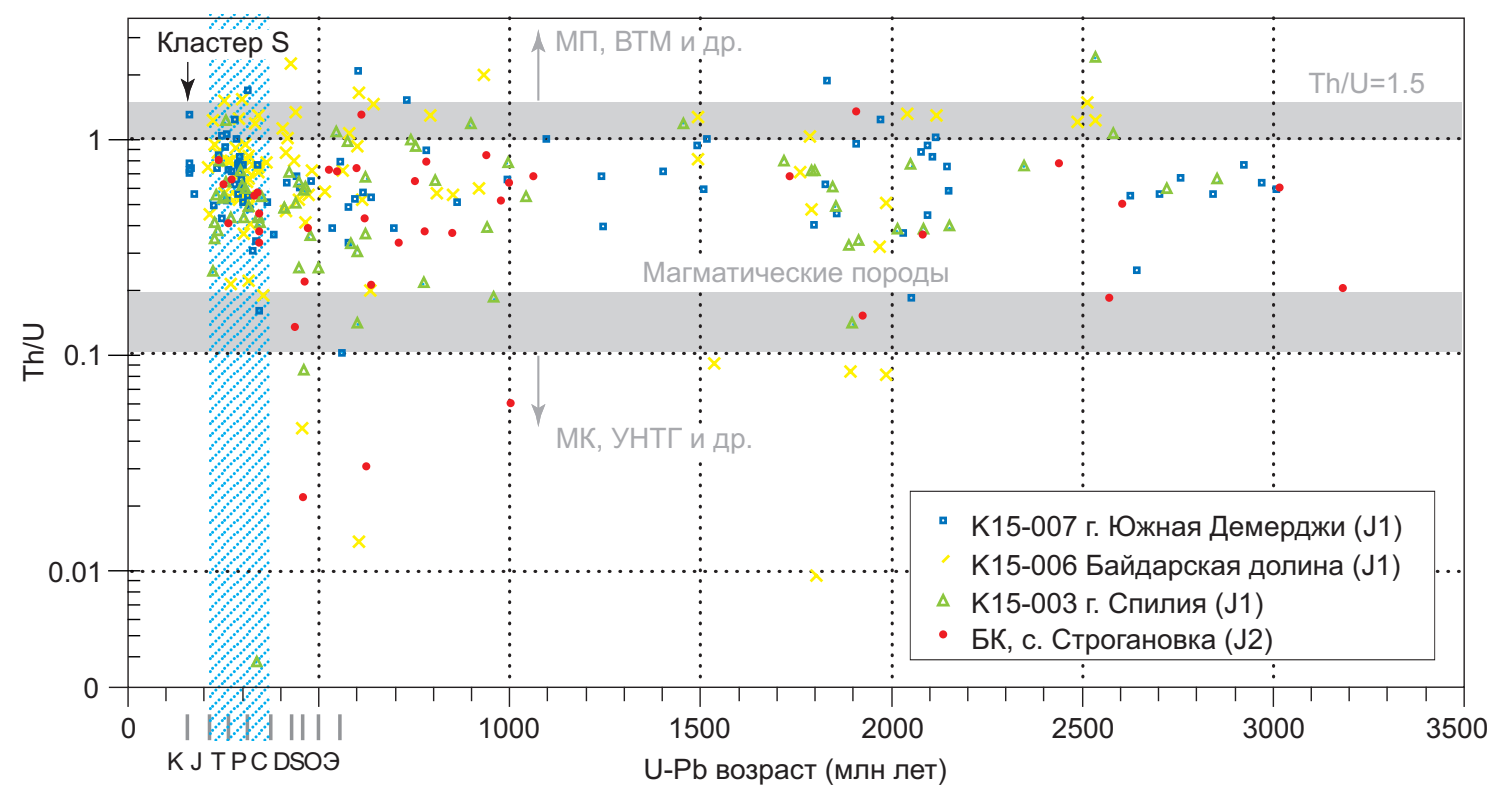

Рис. 6. Диаграмма «Th/U vs U-Pb возраст» для изученных зерен детритового циркона из песчанистых пород средне- и верхнеюрских грубообломочных толщ Горного Крыма.

См. подпись к рис. 4. Светло-серыми полосами маркированы переходы между классификационными полями: магматические породы - обычные интрузивные или вулканические гранитоидные комплексы нормальной или пониженной кремнекислотности, МП - мафические породы, ВТМ - породы, подверженные высокотемпературному метаморфизму, МК - метаморфические породы, в том числе высокобарические, УНТГ - ультранизкотемпературные гранитоидные комплексы. Пояснения см. в тексте.

Fig. 6. Th/U vs U-Pb age diagram for the studied detrital zircon grains from sandy rocks of the Middle and Upper Jurassic coarse clastic strata of the Mountainous Crimea.

See the caption of Fig. 4. Light gray stripes indicate transitions between classification fields: igneous rocks - normal intrusive or volcanic granitoid complexes of normal or low silicic acid, МП - mafic rocks, BTM - rocks subject to high-temperature metamorphism, MK metamorphic rocks, including high-pressure ones, УНТГ - ultralow-temperature granitoid complexes. Explanations in the text. 
В противоположность этому, среди зерен dZr из песчанистых пород верхнеюрских грубообломочных толщ ГК зафиксированы немногочисленные зерна dZr с повышенными величинами Th/U.

Также можно отметить семь зерен dZr с пониженными значениями Th/U и возрастом в интервале от позднего неопротерозоя до раннекаменноугольного ( 650-350 млн лет). Источниками этих зерен dZr могли быть метаморфические комплексы, в том числе эклогитовые. Однако зерна dZr с пониженными значениями Th/U в пробах БК, К15-006, К15-003, К15-007 имеют существенно различные значения возраста. Фигуративные точки этих dZr на диаграмме «Th/U vs U-Pb возраст» не группируются в компактные кластеры, которые можно было бы соотнести со специфическими локальными источниками и попытаться идентифицировать в пределах Крыма или в ближайших к Крыму регионах Причерноморья. Таким образом, по полученным данным дать какую-либо надежную содержательную интерпретацию величин $\mathrm{Th} / \mathrm{U}$ в зернах $\mathrm{dZr}$ из песчанистых пород средне- и верхнеюрских грубообломочных толщ в геологических терминах не представляется возможным.

\section{4. ВЕЩЕСТВЕННЫЕ ХАРАКТЕРИСТИКИ КАМЕННОУГОЛЬНО-ТРИАСОВОГО ПЕРИОДА МАГМАТИЗМА В ПРИЧЕРНОМОРЬЕ ПО РЕЗУЛЬТАТАМ ИЗОТОПНО-ГЕОХИМИЧЕСКОГО ИЗУЧЕНИЯ ЗЕРЕН ДЕТРИТОВОГО ЦИРКОНА ИЗ МЕЗОЗОЙСКИХ И КАЙНОЗОЙСКИХ ТОЛЩ ГОРНОГО КРЫМА}

Во всех изученных пробах песчанистых пород из средне- и верхнеюрских грубообломочных толщ ГК превалируют зерна dZr с возрастами, попадающими в каменноугольно-триасовый интервал (см. рис. $4 ; 7$, a-г). Подобная, но еще более яркая картина характерна для суммарной КПВ по всем четырем пробам (далее КПВ-J) (рис. 8). В работе [Nikishin et al., 2015b] опубликованы суммарные данные для набора проб песчаников Южного берега Крыма, попадающих в стратиграфический интервал от средней юры до неогена (рис. 8). Далее для краткости КПВ по этим данным называется КПВ-N.

Все данные вместе показывают, что в каменноугольно-триасовый временной интервал в пределах Причерноморья имела место магматическая активность, при этом в позднедевонское и раннеюрское время фиксируются относительные магматические затишья.

Для зерен dZr из песчанистых пород верхней толщи конгломератов г. Южная Демерджи (проба К15-007) и толщи конгломератов г. Спилия (проба К15-003), кроме U-Pb датирования были выполнены определения элементов-примесей и получены Hf-изотопные характеристики (см. рис. 7, д, е). Это позволяет получить дополнительные сведения о некоторых вещественных и изотопно-геохимических особенностях продуктов магматизма, проявленного в Причерноморье в каменноугольно-триасовое время.
В целом, прогнозными материнскими породами для зерен dZr каменноугольно-триасового возрастного диапазона, судя по содержанию элементов-примесей в них, наиболее вероятно, были гранитоиды нормальной и/или повышенной кремнекислотности или их вулканические аналоги (см. рис. 7, д, е, фигуративные точки этих dZr показаны как «граниты»). Только небольшая доля зерен dZr каменноугольно-триасового возрастного диапазона могла происходить из пород пониженной кремнекислотности (см. рис. 7, д, е, фигуративные точки этих dZr показаны как «диориты») или других типов пород. Нf-изотопные характеристики зерен dZr каменноугольно-триасового возрастного диапазона не свидетельствуют о сколько-нибудь значительном вкладе корового материала старше мезопротерозоя в субстрат магм, из которых кристаллизовались породы, материнские для зерен dZr.

В выделяемом каменноугольно-триасовом эпизоде магматической активности намечаются три этапа (см. рис. 7, рис. 8).

Этап I. Для этапа I (карбон, 360-315 млн лет, на рис. 7, д, е, ему соответствуют группы зерен циркона D4 и B3) на всех КПВ для возрастов зерен dZr из песчанистых пород средне- и верхнеюрских грубообломочных толщ ГК отчетливо проявлены яркие пики, близкие к возрастным оценкам 334-333 млн лет. На КПВ-J, построенной по суммарному набору возрастов зерен dZr из проб К15-003, K15-007, K15-006 и БК, соответствующий пик333 млн лет - проявлен еще более отчетливо. Этот пик, с учетом ошибок измерений, согласуется с пиком 325 млн лет на КПВ-N, построенной по суммарному набору возрастов зерен dZr из проб песчаников Южного берега Крыма, попадающих в стратиграфический интервал от средней юры до неогена (рис. 8).

Все изученные зерна dZr из проб К15-003 и К15007, соответствующие по возрасту этапу I, показали только отрицательные значения $\varepsilon_{\mathrm{Hf}}=(-2 \ldots-6)$. Все это указывает на весьма ограниченный по площади и относительно близкий доминирующий специфический первичный источник цирконов внутриплитного происхождения.

Этап II. Следующий этап (пермь, 315-270 млн лет, на рис. 7 , д, е, ему соответствуют группы зерен циркона D3 и B2), возможно, самый интенсивный из трех магматических этапов. Для зерен dZr из проб К15-003 и К15-007, соответствующих магматизму этапа II, зафиксирован большой размах вариаций $\varepsilon_{\mathrm{Hf}}=(-13 \ldots+12)$, хотя для большинства зерен $\varepsilon_{\text {нf }}$ не сильно отличается от 0: $\varepsilon_{\text {Hf }}=(-5 \ldots+5)$. Такие вертикальные ряды значений $\varepsilon_{\text {Hf }}$ с большим размахом от низких отрицательных до высоких положительных значений, сопоставимых с деплетированной мантией (линия DM на диаграммах $\left.\varepsilon_{\text {нf }}\right)$, типичны при смешении ювенильного мантийного и изотопно-зрелого корового материала в вулканических дугах, основанием для которых служат блоки континентальной коры. Чем древнее коровые породы в основании дуги, тем ниже в отрицательную область может уходить ряд. 

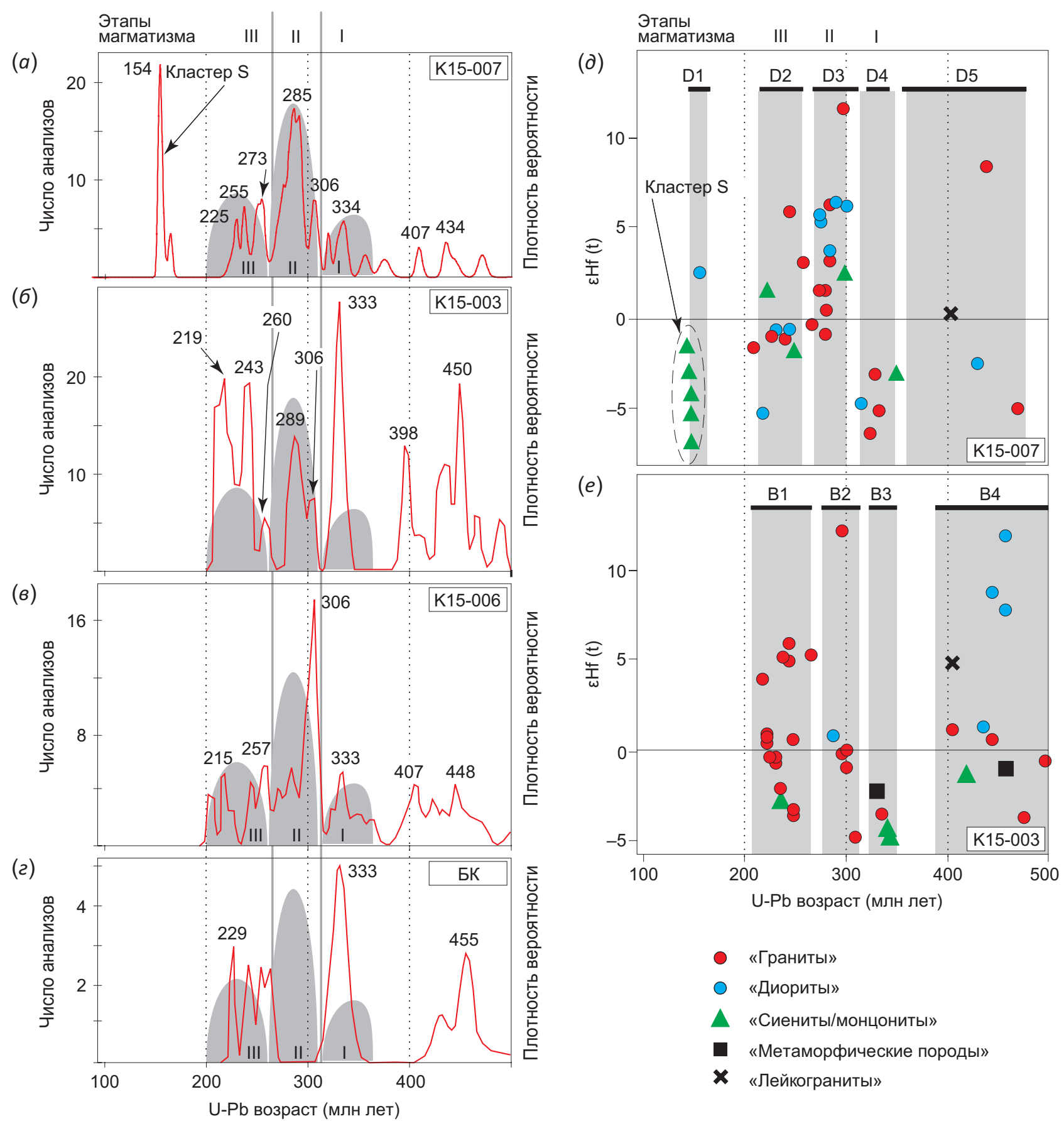

Рис. 7. Результаты изучения зерен детритового циркона из средне- и верхнеюрских грубообломочных толщ Горного Крыма. См. подпись к рис. 4. $(a-2)$ - сопоставление U-Pb возрастов dZr из проб К15-003, K15-007, К15-006 и БК в интервале значений возраста 100-500 млн лет. Серые поля маркируют три этапа (I, II и III) магматической активности: 360-315 млн лет, 315270 млн лет и 270-200 млн лет соответственно. В самом конце девона и начале юры фиксируются относительные магматические затишья. $(\partial, e)$ - диаграммы « $\varepsilon_{\text {нf }} v s$ U-Pb возраст» для проб К15-003 и К15-007 в интервале значений возраста 100500 млн лет, по [Kuznetsov et al., 2019]. Аббревиатуры B1-B4 и D1-D5 в верхних частях диаграмм маркируют выделенные группы зерен циркона, а черные горизонтальные полосы и соответствующие им серые вертикальные поля показывают возрастные интервалы этих групп. Прогнозируемый тип материнских пород зерен циркона на основе содержаний элементовпримесей в изученных цирконах (см. детали в [Kuznetsov et al., 2019]) показан символами.

Fig. 7. Results of the study of detrital zircon grains from the Middle and Upper Jurassic coarse clastic strata of the Mountainous Crimea. See the caption of Fig. 4. (a-2) - comparison of U-Pb ages for dZr from samples K15-003, K15-007, K15-006 and БК in the age range of 100-500 Ma. Gray fields mark the three stages of magmatic activity: 360-315 Ma (I), 315-270 Ma (II), and 270 - 200 Ma (III). Relative magmatic lulls occurred at the very end of the Devonian and the beginning of the Jurassic. $(\partial, e)-\varepsilon_{\mathrm{Hf}} v s \mathrm{U}$-Pb age diagrams for samples K15-003 and K15-007 in the age range of 100-500 Ma (after [Kuznetsov et al., 2019]). Abbreviations B1-B4 and D1-D5 in the upper parts of the diagrams mark the selected zircon groups. Black horizontal stripes and corresponding gray vertical fields show the age ranges of these groups. The types of parental zircon rocks, which are predicted from the contents of trace-elements (see details in [Kuznetsov et al., 2019]), are shown by symbols. 
Этап III. Для заключительного этапа (самый конец перми - триас, 270-200 млн лет, на рис. 7, д, е, ему соответствуют группы зерен циркона D2 и B1) зафиксированы лишь изменения значений $\varepsilon_{\text {н' }}$ попадающие в узкий диапазон $(-5 \ldots+5)$. Таким образом, во время этапа III среди кристаллических пород, служивших первичными источниками зерен dZr, не было ни пород с изотопными характеристиками, сопоставимыми с деплетированной мантией, ни пород, в протолите которых было заметное участие древнего корового материала.

В возрастном интервале, соответствующем II и III этапам магматизма, фиксируются существенные расхождения как между отдельными КПВ, построенными по наборам возрастов зерен dZr из проб К15-003, K15007, К15-006 и БК (см. рис. 7, а-г), так и между КПВ-Ј и КПВ-N (рис. 8). Так, для этапа II характерны значи- тельные вариации как пиковых значений, так и интенсивности пиков в КПВ, построенных по пробам К15003, K15-007, K15-006, а в возрастном наборе dZr из песчанистых пород толщи битакских конгломератов (проба БК) этот этап вообще не проявлен. Из совпадений можно отметить проявление пика 306 млн лет в трех пробах, близкие максимумы на отметках КПВ 285 и 289 млн лет в двух пробах, а также близкие максимумы на отметках КПВ 280 и 285 млн лет в КПВ-Ј и КПВ-N.

Это свидетельствует о том, что, скорее всего, средне- и позднеюрский бассейн, в котором формировались рассматриваемые грубообломочные толщи, был сильно фрагментирован, вплоть до полной изоляции отдельных фрагментов бассейна с образованием суббассейнов, что препятствовало перемешиванию осадочного материала.



Рис. 8. Сопоставление кривых плотности вероятности $(К П В)$ возрастов зерен детритового циркона из мезозойско-кайнозойских осадочных пород Горного Крыма в интервале значений возраста $<1$ млрд лет.

Цифры в кружках: 1 - интегральная КПВ-J, суммирующая результаты U-Pb датирования зерен детритового циркона из среднеи верхнеюрских грубообломочных толщ Горного Крыма (4 пробы, n=269, отдельные КПВ показаны на рис. 4 и 7); 2 - КПВ-N, суммирующая данные по девяти пробам среднеюрских - неогеновых песчаников Горного Крыма (по [Nikishin et al., 2015b], $\mathrm{n}=602) . \mathrm{n}$ - число анализов, использованных для построения КПВ. Серые овалы соответствуют таковым на рис. 7 и маркируют три этапа магматической активности: 360-315 млн лет, 315-270 млн лет и 270-200 млн лет.

Fig. 8. Comparison of probability density plots $(P D P)$ of the ages of detrital zircon grains from Mesozoic-Cenozoic sedimentary rocks of the Mountainous Crimea in the age interval $<1 \mathrm{Ga}$.

Numbers in circles: 1 - integral PDP-J, summarizing the results of U-Pb dating of detrital zircon grains from Middle and Upper Jurassic coarse clastic strata of the Mountainous Crimea (4 samples, $\mathrm{n}=269$, individual PDP are shown in Figs. 4 and 7); 2 - PDP-N summarizing the data on 9 samples of Middle Jurassic-Neogene sandstones of the Mountainous Crimea (after [Nikishin et al., 2015b], n=602). n number of analyzes used to construct the PDP. Gray ovals correspond to those in Fig. 7 and mark the three stages of magmatic activity: 360-315 Ma (I), 315-270 Ma (II), and 270-200 Ma (III). 


\section{5. ПАЛЕОТЕКТОНИЧЕСКАЯ ИНТЕРПРЕТАЦИЯ ПЕРВИЧНЫХ ИСТОЧНИКОВ ЗЕРЕН ДЕТРИТОВОГО ЦИРКОНА ИЗ ПЕСЧАНИСТЫХ ПОРОД СРЕДНЕ- И ВЕРХНЕЮРСКИХ ГРУБООБЛОМОЧНЫХ ТОЛЩ ГОРНОГО КРЫМА}

Полученные интегральные изотопно-геохронологические характеристики зерен dZr из песчанистых пород средне- и верхнеюрских грубообломочных толщ ГК очень хорошо согласуются с палеотектоническими реконструкциями для ЧЕБАК региона, представленными в работах [Nikishin et al., 2015a, 2015b; Okay, Nikishin, 2015; Okay, Topuz, 2016; Rolland et al., 2016; Çimen et al., 2018; Okay et al., 2018; и др.] и схематично показанными на рис. 9.

В работе [Kuznetsov et al., 2019] было показано, что в архейских и палеопротерозойских зернах детритового циркона из проб К15-007 и К15-003 зафиксирован возраст и Hf-изотопные характеристики, не типичные для кристаллических комплексов Украинского щита, для которых характерен возраст от 2.6 до 3.7 млрд лет и модельный возраст субстрата до 3.9 млрд лет (см. также обзор в [Nikishin et al., 2020]). Среди зерен dZr из пробы К15-006 также не выявлено древних: максимальный полученный возраст достигает только $2521 \pm 11$ млн лет $(\mathrm{D}=0.4 \%)$. Таким образом, новые данные по пробе К15-006 еще более статистически надежно подкрепляют вывод о том, что продукты разрушения кристаллических пород из комплексов, аналогичных комплексам Украинского щита (и в целом фундамента юго-западной части ВЕП), не попадали в осадочный бассейн, в котором формировались средне- и верхнеюрские грубообломочные породы ГК, даже за счет рециклирования. Первичными источниками зерен циркона с возрастом древнее 360 млн лет в породах средне- и верхнеюрских грубообломочных толщ ГК могли быть только кристаллические комплексы Гондваны. Террейны, которые последовательно откалывались от северной окраины Гондваны и затем причленялись к южной периферии балтийской части Евразии, были переносчиками этих зерен dZr, неоднократно рециклированных через осадочные толщи.

Напротив, все зерна dZr каменноугольно-триасового возраста в изученных пробах имеют региональное происхождение и были сгенерированы в окраинноконтинентальных или внутриокеанических структурах океанов Реик и Палеотетис.

Гранитоидные комплексы с возрастом 360-315 млн лет, соотносимые с этапом I, в настоящее время широко экспонируются во многих структурах ЧЕБАК региона. Повсеместно проявленный в этих структурах HT-LP метаморфизм во временном промежутке 340-330 млн лет [Okay, Topuz, 2016] в работе [Rolland et al., 2016] был соотнесен со «сломом слэба» океана Реик. В частности, детальное изучение циркона из пород Дзирульского массива в Закавказье показало пиковый возраст метаморфизма около 337 млн лет и только отрицательные $\varepsilon_{\mathrm{Hf}}=(-2 \ldots-10)$ [Mayringer et al., 2011]. Идеальное совпадение как возрастных, так и Hf-изотопных характеристик изученных зерен циркона из пород Дзирульского массива с таковыми для зерен циркона из песчанистых пород грубообломочных толщ ГК делает Дзирульский массив и его аналоги на Кавказе наиболее вероятным первичным источником таких зерен циркона.

Этапы II (315-270 млн лет) и III (270-200 млн лет) магматизма в ЧЕБАК регионе соотносятся с функционированием Скифско-Понтидского вулканического надсубдукционного пояса, что согласуется с Hf-изотопными характеристиками зерен циркона этих возрастов из изученных грубообломочных пород ГК (см. п. 4). Нечеткое разделение этапов магматической активности и относительное преобладание зерен циркона, соответствующих по возрасту магматическому этапу II, над зернами этапа III в изученных пробах может быть связано как с изменениями магматической активности в различных сегментах пояса, так и с изменениями интенсивности эрозии кристаллических комплексов на последующих этапах эволюции, вызванными тектоническими перестройками внутри океана Палеотетис.

В настоящее время крупные гранитоидные комплексы с возрастом 315-270 млн лет (этап II) известны в Западных Понтидах и в Южных Балканах [Sunal et al., 2008; Meinhold et al., 2010; Georgiev et al., 2012; Ustaomer et al., 2012; Kaygusuz et al., 2016; Peytcheva et al., 2018]. Однако только редкие кристаллические комплексы с возрастом 270-200 млн лет (этап III) известны в ЧЕБАК регионе. Прежде всего это комплексы и массивы триасовой гранитоидной провинции Северной Добруджи [Savu, 2012]. Следы триасовой магматической активности известны в Степном Крыму (кварцевые долериты и кварцевые диориты с возрастом 210 млн лет около пос. Северный [Spiridonov et al., 1990]) и Восточном Закавказье [Tikhomirov et al., 2004]. В Понтидах распознаны реликты триасовых магматических комплексов, соотносимых с океаническими горами, островами и плато [Genc, 2004; Sayit et al., 2010], а также голубые сланцы и эклогиты [Okay, Nikishin, 2015] и сложенный адакитоподобными породами плутон [Çimen, 2020], являющиеся индикаторами триасовой субдукционной зоны в Причерноморском регионе. Все эти комплексы могли быть первичными источниками зерен dZr соответствующего возраста для юрских конгломератов ГК.

Кристаллические комплексы со среднеюрским возрастом в настоящее время широко представлены в ГК. Это магматиты Первомайского штока, Джидаирской интрузии, Гераклеи и Карадага (см. рис. 1). Кристаллические комплексы со средне- и верхнеюрским возрастом широко распространены в настоящее время в Понтидах и на Кавказе [Genc, Tuysuz, 2010]. На КПВ-N хорошо проявлены соответствующие средне- и позднеюрский пики - 170 и 150 млн лет (см. рис. 8). Однако ни в одной из проб из обсуждаемых здесь толщ средне- и верхнеюрских конгломератов ГК зерна dZr с юрским возрастом не зафиксированы, за исключением шести зерен циркона группы D1 в пробе К15-007 (пять зерен циркона кластера S с возрастом около 154 млн лет + 1 циркон с возрастом 164 млн лет), которые интерпретируются 


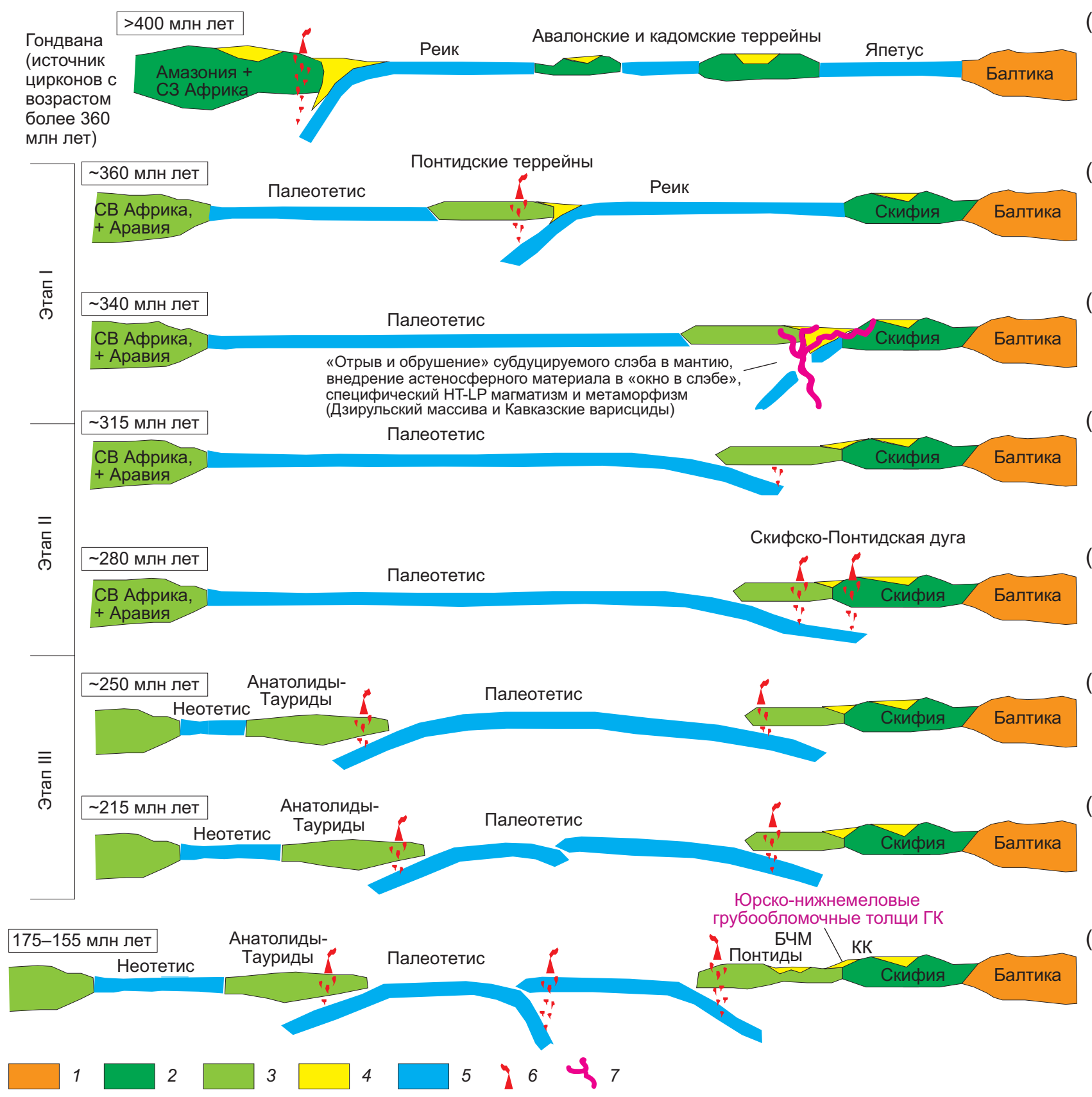

(a)

(б)

(в)

(2)

(d)

(e)

(ж)

Рис. 9. Концептуальная схема основных этапов тектонической эволюции Черноморско-Балканско-Анатолийско-Кавказского региона (ЧЕБАК региона) в фанерозое, показывающая первичные источники зерен детритового циркона из песчанистых пород средне- и верхнеюрских грубообломочных толщ Горного Крыма.

Основа рисунка - модель, предложенная в работе [Rolland et al., 2016], (a) - по [Nance, Linnemann, 2008]. Схема предельно генерализирована/упрощена и не отражает многих деталей эволюции региона.

1 - Балтика (докембрийский фундамент Восточно-Европейской платформы); 2 - Амазония (докембрийский фундамент Южной Америки) и Северо-Западная Африка; 3 - Северо-Восточная Африка и Аравия; 4 - осадочные комплексы, через которые могло произойти рециклирование цирконов из первичных источников в юрские грубообломочные породы Горного Крыма; 5 - океаническая кора; 6 - надсубдукционный вулканизм; 7 - специфический вулканизм и метаморфизм, спровоцированный проникновением астеносферного материала в «окно в слэбе». $(a)$ - в позднем докембрии и кембрии от амазонской и северо-западной африканской части Гондваны откололись авалонские и кадомские террейны, которые вместе с внутриокеаническими образованиями океана Реик в раннем палеозое были присоединены к западной и юго-западной окраине Балтики, некоторые из террейнов за счет сдвиговых движений в восточном направлении отдрейфовали до юго-восточной периферии Балтики. В настоящее время эти террейны являются остовом фундамента некоторых областей Западной Европы, Мизийской и Скифской (в состав которой входит Степной Крым) платформ. (б) - около рубежа 360 млн лет от Гондваны откололись понтидские террейны, которые стали дрейфовать в сторону Балтики, а между ними и Гондваной стал раскрываться океан Палеотетис. Авалонские, кадомские и понтидские террейны были переносчиками цирконов с возрастом древнее 360 млн лет из Гондваны в район современного Причерноморья. (в) - причленение понтидских террейнов к Балтике и Скифии завершилось «отрывом и обрушением» субдуцируемого слэба океана Реик в мантию около рубежа 340-330 млн лет. Внедрение 
астеносферного материала в образовавшееся «окно в слэбе» вызвало кратковременный специфический HT-LP магматизм и метаморфизм. (2-д) - около рубежа 315 млн лет под южную окраину Балтики, наращенную авалонскими, кадомскими и понтидскими террейнами, заложилась новая субдукционная зона - Скифско-Понтидская вулканическая дуга (2), пик магматической активности в которой достиг максимума около 280 млн лет (d). (e) - около рубежа 250 млн лет от северного края Гондваны откололись киммерийские террейны (начало открытия океана Неотетис), которые начали дрейфовать в сторону Балтики. В настоящее время часть этих террейнов (Анатолиды-Тауриды) является остовом Анатолийского полуострова. (ж) около рубежа 200 млн лет началось заложение Черноморской впадины в тылу у Скифско-Понтидской вулканической дуги, а внутри океана Палеотетис продолжались тектонические перестройки, сопровождавшиеся магматической активностью. (3) в средней и верхней юре продолжилось раскрытие океана Неотетис и началось раскрытие Черноморской впадины, а в Палеотетисе функционировали внутриокеанические вулканические дуги и продолжались тектонические перестройки. БЧМ будущая Черноморская впадина, КК - киммериды Крыма.

Fig. 9. Conceptual scheme of the main stages of the tectonic evolution of the Black Sea-Balkan-Anatolian-Caucasian region (BSBAC region) in the Phanerozoic. It shows the primary sources of detrital zircon grains from sandy rocks of the Middle and Upper Jurassic coarse clastics of the Mountainous Crimea.

This conceptual scheme is based on the model proposed in [Rolland et al., 2016]. Figure (a) is according to [Nance, Linnemann, 2008]. The scheme is extremely generalized and simplified and thus does not reflect many details of the evolution of the region.

1 - Baltica (Precambrian basement of the East European platform); 2 - Amazonia (Precambrian basement of South America) and northwestern Africa; 3 - northeastern Africa and Arabia; 4 - sedimentary complexes through which recycling of zircons from the primary sources to the Jurassic coarse rocks of the Mountainous Crimea could have occurred; 5 - oceanic crust; 6 - suprasubduction volcanism; 7 - specific volcanism and metamorphism provoked by the penetration of asthenospheric material into «a window in the slab». (a) - in the Late Precambrian and Cambrian, the Avalonian and Cadomian terrenes had broken off the Amazonian and northeastern African parts of Gondwana, which, together with the oceanic formations of the Reik Ocean, were docked in the Early Paleozoic to the western and southwestern margins of Baltica. Some of the terrenes had drifted due to shear movements eastward, to the southeastern periphery of Baltica. Currently, these terrenes are the basement of some regions of West Europe, the Moesian and Scythian (which includes the Steppe Crimea) platforms. (б) - near $360 \mathrm{Ma}$, Pontidian terrenes had broken off Gondwana and began to drift towards Baltica. The Paleotethys ocean began to open between them and Gondwana. Avalonian, Cadomian and Pontidian terrenes carried the zircons with ages older than 360 Ma from Gondwana to the region of the present-day Black Sea. ( 8 ) - collision the Pontidian terranes with Baltica and Scythia completed after the subducted slab of the Reik ocean 'broke off and collapsed' into the mantle near 340 - 330 Ma. Asthenospheric material flowing into 'a window in the slab' caused short-term specific HT-LP magmatism and metamorphism. (2- $\partial$ ) near $315 \mathrm{Ma}$, a new subduction zone was initiated underneath the southern margin of the Baltica, which was built up with the Avalonian, Cadomian and Pontidian terrenes - the Scythian-Pontidian volcanic arc (2). Magmatic activity in this arc reached its maximum about $280 \mathrm{Ma}(\partial)$. (e) - near $250 \mathrm{Ma}$, Cimmerian terrenes had broken off from the northern edge of Gondwana (the beginning of the Neotethys ocean opening) and began to drift towards Baltica. Currently, a part of these terrenes (Anatolides-Taurides) is the basement of the Anatolian Peninsula. (ж) - Near 200 Ma, the Black Sea back-arc basin began to form behind the Scythian- Pontidian volcanic arc, and tectonic transformation of Paleotethys ocean continued and was accompanied by magmatic activity. (3) - in the Middle and Upper Jurassic, the Neotethys ocean continued to open; the Black Sea basin began to open; intra-oceanic volcanic arcs functioned in the Paleotethys ocean, and its tectonic transformation continued. БЧМ - future Black Sea basin, КК - Crimean Cimmerides.

как произошедшие из локального источника. Это определенно свидетельствует о том, что ни юрские кристаллические комплексы, за исключением единичного локального источника зерен циркона кластера S, ни осадочные образования, в которых могли быть аккумулированы продукты разрушения юрских кристаллических комплексов, в момент формирования рассматриваемых здесь толщ средне- и верхнеюрских конгломератов на палеоводосборах не экспонировались. Однако впоследствии в более поздние осадочные образования ГК зерна циркона со среднеюрским и позднеюрским возрастом попадали в большом количестве. Вместе с отмеченными особенностями КПВ из изученных проб (см. п. 4) это свидетельствует о том, что в средней и поздней юре в части ЧЕБАК региона, соответствующей современному ГК, установился геодинамический режим, близкий, по сути, современному геодинамическому режиму Провинции Бассейнов и Хребтов, где растяжение коры создало чередование хребтов и небольших по площади и не связанных между собой рифтоподобных бассейнов. Водосбор в бассейны осуществляется с очень ограниченных площадей: только непосредственно с бортов бассейнов. Среднеюрский магматизм ГК соответствует самым начальным фазам растяжения коры, которое впоследствии завершилось формированием Черноморской впадины [Nikishin et al., 2015a]. Когда на более поздних стадиях растяжения образовался общий обширный бассейн, началось смешение местных и удаленных осадочных потоков и усреднение провенанс-сигналов, поэтому в более поздние осадочные образования ГК юрские и более молодые зерна циркона попали.

\section{6. ЗАКЛЮЧЕНИЕ}

Получены результаты U-Pb изотопного датирования зерен dZr из песчанистых пород верхнеюрской части разреза грубообломочной толщи, обнаженной на восточном борту Байдарской котловины около с. Орлиное. Сопоставление этих датировок с полученными ранее результатами изучения зерен $\mathrm{dZr}$ из верхнеюрских конгломератов, слагающих склоны г. Спилия около Балаклавской бухты, верхней толщи конгломератов г. Южная Демерджи около г. Алушты, а также среднеюрских битакских конгломератов около с. Строгановка (пригород г. Симферополя) показало высокую степень 
сходства осредненных возрастных характеристик основных популяций зерен dZr.

Результаты изучения зерен dZr из песчанистых пород средне- и верхнеюрских грубообломочных толщ в четырех локациях ГК вместе с аналогичными данными для суммарного набора возрастов зерен dZr из проб песчаников Южного берега Крыма, попадающих в стратиграфический интервал от средней юры до неогена, позволили статистически надежно охарактеризовать каменноугольно-триасовый (360-200 млн лет) временной интервал магматической активности, проявленной в пределах Причерноморья и ограниченной во времени позднедевонским и раннеюрским относительными магматическими затишьями. В выделяемом каменноугольно-триасовом интервале магматической активности намечаются три этапа: (I) 360-315 млн лет, (II) 315-270 млн лет и (III) 270-200 млн лет.

Этап магматизма I (360-315 млн лет) соотносится с закрытием океана Реик, завершившимся «отрывом и обрушением» субдуцируемого слэба в мантию, сопровождавшимся повсеместно проявленным HT-LP метаморфизмом. Для соответствующих по возрасту этому этапу магматизма зерен dZr из песчанистых пород средне- и верхнеюрских конгломератов ГК характерен пиковый возраст около 340-325 млн лет и доминирование отрицательных $\varepsilon_{\text {нf }}$ Наиболее вероятным первичным источником этих зерен dZr был Дзирульский массив в Закавказье и/или его аналоги на Кавказе.

Этапы магматизма II (315-270 млн лет) и III (270200 млн лет) соотносятся с функционированием надсубдукционного Скифско-Понтидского вулканического пояса. Для зерен dZr, соответствующих по возрасту этим этапам, характерен разброс величин $\varepsilon_{\mathrm{Hf}}$ от слабоотрицательных до существенно положительных, сопоставимых с DM, что типично для вулканических дуг. Первичными источниками зерен dZr с возрастом этапа II могли быть крупные гранитоидные массивы, известные в настоящее время в Западных Понтидах и в Южных Балканах. Однако только редкие малообъемные кристаллические комплексы с возрастом 270-200 млн лет, соответствующие этапу III, известны в ЧЕБАК регионе, и вопрос об источнике триасовых зерен dZr до сих пор дискутируется.

Судя по содержаниям элементов-примесей в зернах $\mathrm{dZr}$ каменноугольно-триасового возраста, доминирующим типом их материнских пород, наиболее вероятно, были гранитоиды нормальной и/или повышенной кремнекислотности и/или их вулканические аналоги. Только небольшая доля зерен dZr могла происходить из гранитоидов пониженной кремнекислотности или других типов пород.

Полученные интегральные характеристики зерен $\mathrm{dZr}$ вместе с имеющейся геологической информацией, палеотектоническими и палеогеографическими реконструкциями позволяют сделать вывод о том, что все зерна dZr каменноугольно-триасового возраста в изученных пробах из песчанистых пород средне- и верхнеюрских грубообломочных толщ имеют региональное происхождение и, наиболее вероятно, были сгенерированы в надсубдукционных структурах Скифско-Понтидского вулканического пояса. Вовлечение древнейшего (палеопротерозойского и старше) корового материала в протолит материнских для изученных зерен $\mathrm{dZr}$ пород маловероятно. Нечеткое разделение II и III этапов магматизма и сильная вариабельность пиковых значений возраста зерен dZr, соответствующих этим этапам, в изученных пробах могут быть связаны как с изменениями магматической активности в различных сегментах Скифско-Понтидского вулканического пояса, так и с изменениями интенсивности эрозии кристаллических комплексов пояса на последующих этапах эволюции, вызванными тектоническими перестройками внутри океана Палеотетис.

\section{7. БЛАГОДАРНОСТИ}

Мы благодарим проф. А.М. Никишина (геологический факультет МГУ им. М.В. Ломоносова, г. Москва) за любезно предоставленные цифровые данные результатов U-Pb датирования зерен dZr из битакских конгломератов, а также рецензентов за их высокопрофессиональные замечания и комментарии, учет которых, несомненно, способствовал улучшению статьи.

\section{8. ЛИТЕРАТУРA / REFERENCES}

Çimen O., 2020. Geochemical Characteristics of the Adakite-Like Dodurga Pluton (Central Pontides, N Turkey): Implications for Middle Triassic Continental Arc Magmatism in Southern Black Sea Region. International Journal of Earth Science 109, 809-829. https://doi.org/10.1007/s00531020-01831-x.

Çimen O., Göncüoğlu M.C., Simonetti A., Sayıt K., 2018. New Zircon U-Pb LA-ICP-MS Ages and Hf Isotope Data from the Central Pontides (Turkey): Geological and Geodynamic Constraints. Journal of Geodynamics 116, 23-36. https:// doi.org/10.1016/j.jog.2018.01.004.

Fikolina L.A., Beletsky S.V., Belokrys O.A., Derenyuk D.N., Krasnorudskaya S.I., Obsharskaya N.N., Korol' B.I., Ivakin M.N., Shevchuk N.V., Dyachenko L.N., Averina V.N., Peresadko I.N., Pupysheva V.G., Sevastyanova V.P., 2019. State Geological Map of the Russian Federation. Scythian Series. Scale 1:1000000. Sheet L-36 (Simferopol). Explanatory Note. VSEGEI, Saint Petersburg, 979 р. (in Russian) [Фиколина Л.А., Белецкий С.В., Белокрыс О.А., Деренюк Д.Н., Краснорудская С.И., Обшарская Н.Н., Король Б.И., Ивакин М.Н., Шевчук Н.В., Дяченко Л.Н., Аверина В.Н., Пересадько И.Н., Пупышева В.Г., Севастьянова В.П. Государственная геологическая карта Российской Федерации масштаба 1:1000000. Серия Скифская. Лист L-36 (Симферополь). Объяснительная записка. СПб.: ВСЕГЕИ, 2019. 979 с.].

Genc S.C., 2004. A Triassic Large Igneous Province in the Pontides, Northern Turkey: Geochemical Data for Its Tectonic Setting. Journal of Asian Earth Sciences 22 (5), 503516. https://doi.org/10.1016/S1367-9120(03)00090-7.

Genc S.C., Tuysuz O., 2010. Tectonic setting of the Jurassic bimodal magmatism in the Sakarya Zone (Central and Western Pontides), Northern Turkey: A Geochemical and 
Isotopic Approach. Lithos 118 (1-2), 95-111. https://doi. org/10.1016/j.lithos.2010.03.017.

Georgiev S., von Quadt A., Heinrich C.A., Peytcheva I., Marchev P., 2012. Time Evolution of a Rifted Continental Arc: Integrated ID-TIMS and LAICPMS Study of Magmatic Zircons from the Eastern Srednogorie, Bulgaria. Lithos 154, 53-67. https://doi.org/10.1016/j.lithos.2012.06.020.

Griffin W.L., Powell W.J., Pearson N.J., O’Reilly S.Y., 2008. GLITTER: Data Reduction Software for Laser Ablation ICP-MS. In: P.J. Sylvester (Ed.), Laser Ablation-ICP-MS in the Earth Sciences: Current Practices and Outstanding Issues. Mineralogical Association of Canada Short Course Series. Vol. 40. Vancouver, 308-311.

Guynn J., Gehrels G., 2010. Comparison of Detrital Zircon Age Distribution Using the K-S Test Visualization and Representation of Age-Distribution Data Histograms. Available from: https://sites.google.com/a/laserchron.org/laserchron/ home (Last Accessed August - October, 2019).

Harrison T.M., Watson E.B., Aikman A.B., 2007. Temperature Spectra of Zircon Crystallization in Plutonic Rocks. Geology 35 (7), 635-638. https://doi.org/10.1130/G23505A.1.

Horstwood M.S.A., Kosler J., Gehrels G., Jackson S.E., McLean N.M., Paton Ch., Pearson N.J., Sircombe K., Sylvester P., Vermeesch P., Bowring J.F., Condon D.J., Schoene B., 2016. Community-Derived Standards for LA-ICP-MS U-(Th-)Pb Geochronology - Uncertainty Propagation, Age Interpretation and Data Reporting. Geostandards and Geoanalytical Research 40 (3), 311-332. https://doi.org/10.1111/j.1751908X.2016.00379.x.

Hoskin P.W., Schaltegger U., 2003. The Composition of Zircon and Igneous and Metamorphic Petrogenesis. Reviews in Mineralogy and Geochemistry 53 (1), 27-62. https://doi. org/10.2113/0530027.

Kaczmarek M.A., Müntener O., Rubatto D., 2008. Trace Element Chemistry and U-Pb Dating of Zircons from Oceanic Gabbros and Their Relationship with Whole Rock Composition (Lanzo, Italian Alps). Contributions to Mineralogy and Petrology 155, 295-312. https://doi.org/10.1007/s00 410-007-0243-3.

Kaygusuz A., Arslan M., Sipahi F., Temizel I., 2016. U-Pb Zircon Chronology and Petrogenesis of Carboniferous Plutons in the Northern Part of the Eastern Pontides, NE Turkey: Constraints for Paleozoic Magmatism and Geodynamic Evolution. Gondwana Research 39, 327-346. https://doi.org/ 10.1016/j.gr.2016.01.011.

Kirkland C.L., Smithies R.H., Taylor R.J.M., Evans N., McDonald B., 2015. Zircon Th/U Ratios in Magmatic Environs. Lithos 212-215, 397-414. https://doi.org/10.1016/j.lithos.2014.11.021.

Kuznetsov N.B., Belousova E.A., Griffin W.L., O'Reilly S.Y., Romanyuk T.V., Rud'ko S.V., 2019. Pre-Mesozoic Crimea as a Continuation of the Dobrogea Platform: Insights from Detrital Zircons in Upper Jurassic Conglomerates, Mountainous Crimea. International Journal of Earth Sciences 108 (7), 24072428. https://doi.org/10.1007/s00531-019-01770-2.

Linnemann U., Ouzegane K., Drareni A., Hofmann M., Becker S., Gärtner A., Sagawe A., 2011. Sands of West Gondwana: An Archive of Secular Magmatism and Plate Interactions - a
Case Study from the Cambro-Ordovician Section of the Tassili Ouan Ahaggar (Algerian Sahara) Using U-Pb-LA-ICP-MS Detrital Zircon Ages. Lithos 123 (1-4), 188-203. https://doi. org/10.1016/j.lithos.2011.01.010.

Ludwig K.R., 2012. User's Manual for Isoplot 3.75. A Geochronological Toolkit for Microsoft Excel. Berkeley Geochronology Center Special Publication 5, 75 p.

Mayringer F., Treloar P.J., Gerdes A., Finger F., Shengella D., 2011. New Age Data from the Dzirula Massif, Georgia: Implications for the Evolution of the Caucasian Variscides. American Journal of Science 311 (5), 404-441. https://doi. org/10.2475/05.2011.02.

Meinhold G., Kostopoulos D., Frei D., Himmerkus F., Reischmann T., 2010. U-Pb LA-SF-ICP-MS Zircon Geochronology of the Serbo-Macedonian Massif, Greece: Palaeotectonic Constraints for Gondwana-Derived Terranes in the Eastern Mediterranean. International Journal of Earth Sciences 99 (4), 813-832. https://doi.org/10.1007/s00 531-009-0425-5.

Mileev V.S., Baraboshkin E.Yu., Rozanov S.B., Rogov M.A., 2006. Cimmerian and Alpine Tectonics of Mountainous Crimea. Bulletin of MOIP. Geology Dept. 81 (3), 22-33 (in Russian) [Милеев В.С., Барабошкин Е.Ю., Розанов С.Б., Рогов М.А. Киммерийская и альпийская тектоника Горного Крыма // Бюллетень МОИП. Отд. геологии. 2006. Т. 81. Вып. 3. С. 22-33].

Mileev B.C., Baraboshkin E.Yu., Rozanov S.B., Rogov M.A., 2009. Tectonics and Geodynamic Evolution of the Mountainous Crimea. Bulletin of MOIP. Geology Dept. 84 (3), 3-22 (in Russian) [Милеев В.С., Барабошкин Е.Ю., Розанов С.Б., Рогов М.А. Тектоника и геодинамическая эволюция Горного Крыма // Бюллетень МОИП. Отд. геологии. 2009. Т. 84. Вып. 3. С. 3-22].

Morozova E.B., Sergeev S.A., Savelev A.D., 2017. Cretaceous and Jurassic Intrusions in Crimean Mountains: The First Data of U-Pb (SIMS SHRIMP) Dating. Doklady Earth Sciences 474 (1), 66-72 (in Russian) [Морозова Е.Б., Cepгеев С.А., Савельев А.Д. Меловые и юрские интрузии Горного Крыма: первые данные U-Pb (SIMS SHRIMP)датирования // Доклады АН. 2017. Т. 474. № 1. С. 66-72]. https://doi.org/10.7868/S086956521713014X.

Nance D.R, Linnemann U., 2008. The Rheic Ocean: Origin, Evolution, and Significance. GSA Today 18 (12), 4-12. https:// doi.org/10.1130/GSATG24A.1.

Nikishin A.M., Gabdullin R.R., Makhatadze G.V., Khudolei A.K., Rubtsova E.V., 2016. Bitak Conglomerates as a Clue for Understanding the Middle Jurassic Geological History of Crimea. Moscow University Bulletin. Series 4. Geology 6, 20-27 (in Russian) [Никишин А.М., Габдуллин Р.P., Махатадзе Г.В., Худолей А.К., Рубцова Е.В. Битакские конгломераты как ключ для понимания среднеюрской геологической истории Крыма // Вестник МГУ. Серия 4. Геология. 2016. № 6. С. 20-27]. https://doi.org/10.33623/ 0579-9406-2016-6-20-27.

Nikishin A.M., Okay A., Tuysuz O., Demirer A., Wannier M., Amelin N., Petrov E., 2015a. The Black Sea Basins Structure and History: New Model Based on New Deep Penetration Regional Seismic Data. Part 2: Tectonic History and 
Paleogeography. Marine and Petroleum Geology 59, 656670. https://doi.org/10.1016/j.marpetgeo.2014.08.018.

Nikishin A.M., Romanyuk T.V., Moskovsky D.V., Kuznetsov N.B., Kolesnikova A.A., Dubensky A.S., Sheshukov V.S., Lyapunov S.M., 2020. Upper Triassic Strata of Mountainous Crimea: The First Results of U-Pb Dating of Detrital Zircons. MSU Bulletin. Series 4. Geology 2, 18-33 (in Russian) [Никишин А.М., Романюк Т.В., Московский Д.В., Кузнецов Н.Б., Колесникова А.А., Дубенский А.С., Шешуков В.С., Ляпунов С.М. Верхнетриасовые толщи Горного Крыма: первые результаты U-Pb датирования детритовых цирконов // Вестник МГУ. Серия 4. Геология. 2020. № 2. С. 18-33].

Nikishin A.M., Wannier M., Alekseev A.S., Almendinger O.A., Fokin P.A., Gabdullin R.R., Khudoley A.K., Kopaevich L.F., Mityukov A.V., Petrov E.I., Rubsova E.V., 2015b. Mesozoic to Recent Geological History of Southern Crimea and the Eastern Black Sea Region. In: M. Sosson, R.A. Stephenson, S.A. Adamia (Eds), Tectonic Evolution of the Eastern Black Sea and Caucasus. Geological Society of London Special Publications 428 (1), 241-264. https://doi.org/10.1144/SP428.

Okay A.I., Nikishin A.M., 2015. Tectonic Evolution of the Southern Margin of Laurasia in the Black Sea Region. International Geology Review 57 (5-8), 1051-1076. https:// doi.org/10.1080/00206814.2015.1010609.

Okay A., Topuz G., 2016. Variscan Orogeny in the Black Sea Region. International Journal of Earth Sciences 106, 569-592. https://doi.org/10.1007/s00531-016-1395-z.

Okay A.I., Altiner D., Sunal G., Aygul M., Akdogan R., Altiner S., Simmons M., 2018. Geological Evolution of the Central Pontides. In: M.D. Simmons, G.C. Tari, A.I. Okay (Eds), Petroleum Geology of the Black Sea. Geological Society of London Special Publications 464 (1), 33-67. https://doi. org/10.1144/SP464.

Peytcheva I., Tacheva E., von Quadt A., Nedialkov R., 2018. $\mathrm{U}-\mathrm{Pb}$ Zircon and Titanite Ages and Sr-Nd-Hf Isotope Constraints on the Timing and Evolution of the Petrohan-Mezdreya Pluton (Western Balkan Mts, Bulgaria). Geologica Balcanica 47 (2), 25-46.

Popov D.V., Brovchenk V.D., Nekrylov N.A., Plechov P.Yu., Spikings R.A., Tyutyunnik O.A., Krigman L.V., Anosova M.O., Kostitsyn Y.A., Soloviev A.V., 2019. Removing a Mask of Alteration: Geochemistry and Age of the Karadag Volcanic Sequence in SE Crimea. Lithos 324-325, 371-384. https:// doi.org/10.1016/j.lithos.2018.11.024.

Promyslova M.Y., Demina L.I., Bychkov A.Y., Gushchin A.I., Koronovsky N.V., Tsarev V.V., 2016. Ophiolitic Association of the Cape Fiolent Area, Southwestern Crimea. Geotectonics 50, 21-34. http://dx.doi.org/10.1134/S0016852116010040.

Rolland Y., Hässig M., Bosch D., Meijers M.J.M., Sosson M., Bruguier O., Adamia Sh., Sadradze N., 2016. A Review of the Plate Convergence History of the East Anatolia-Transcaucasus Region during the Variscan: Insights from the Georgian Basement and Its Connection to the Eastern Pontides. Journal of Geodynamics 96, 131-145. http://dx.doi. org/10.1016/j.jog.2016.03.003.

Romanyuk T.V., Kuznetsov N.B., Belousova E.A., Gorozhanin V.M., Gorozhanina E.N., 2018. Paleotectonic and Paleogeographic Conditions for the Accumulation of the Lower
Riphean Ai Formation in the Bashkir Uplift (Southern Urals): The «TerraneChrone $® »$ Detrital Zircon Study. Geodynamics \& Tectonophysics 9 (1), 1-37 (in Russian) [Романюк T.B., Кузнецов Н.Б., Белоусова Е.А., Горожанин В.М., Горожанина Е.Н. Палеотектонические и палеогеографические обстановки накопления нижнерифейской айской свиты Башкирского поднятия (Южный Урал) на основе изучения детритовых цирконов методом «TerraneChrone®» // Геодинамика и тектонофизика. 2018. Т. 9. № 1. С. 1-37]. https://doi.org/10.5800/GT-2018-9-1-0335.

Rud'ko S.V., 2018. Upper Jurassic Rock Depositional Settings in the Baidar Valley and Evolution of the Crimean Carbonate Platform. Lithology and Mineral Resources 53, 307323. http://dx.doi.org/10.1134/S0024490218040065.

Rud'ko S.V., Kuznetsov N.B., Belousova E.A., Romanyuk T.V., 2018. Structure and the Age of Conglomerates of Mount Southern Demerdzhi Based on the First U/PbDating of Detrital Zircons (Upper Jurassic, Crimean Mountains). Doklady Earth Sciences 483, 1423-1426. http:// dx.doi.org/10.1134/S1028334X18110223.

Rud'ko S.V., Kuznetsov N.B., Belousova E.A., Romanyuk T.V., 2019. Age, Hf-Isotope Systemantic of Detritial Zircons and the Source of Conglomerates of the Southern Demerdzhi Mountain, Mountaineous Crimea. Geotectonics 53, 569-587. https://doi.org/10.1134/S0016852119050042.

Rud'ko S.V., Pokrovsky B.G., Kuznetsov A.B., 2017. Sr Chemostratigraphy, $\delta^{13} \mathrm{C}$, and $\delta^{18} \mathrm{O}$ of Rocks in the Crimean Carbonate Platform (Late Jurassic, Northern Peri-Tethys). Lithology and Mineral Resources 52, 479-497. http://dx. doi.org/10.1134/S0024490217060086.

Savu H., 2012. The North Dobrogea Granite Province: Petrology and Origin of Its Rocks. Bucharest, Romanian Journal of Geology 56 (1-2), 3-15.

Sayit K., Goncuoglu M.C., Furman T., 2010. Petrological Reconstruction of Triassic Seamounts. Oceanic Islands within the Palaeotethys: Geochemical Implications from the Karakaya Subduction/Accretion Complex, Northern Turkey. Lithos 119 (3-4), 501-511. http://dx.doi.org/10.1016/j. lithos.2010.08.004.

Soloviev A.V., Rogov M.A., 2010. First Fission-Track Dating of Zircons from Mesozoic Complexes of the Crimea. Stratigraphy and Geological Correlation 18, 298-306. https:// doi.org/10.1134/S0869593810030068.

Spiridonov E.M., Fedorov T.O., Ryakhovsky V.M., 1990. Magmatic Formations of the Mountainous Crimea. Article 1. Bulletin of MOIP. Geology Deptartment 65 (4), 119-133 (in Russian) [Спиридонов Э.М., Федоров Т.О., Ряховский В.М. Магматические образования Горного Крыма. Статья 1 // Бюллетень МОИП. Отделение геологии. 1990. Т. 65. Вып. 4. C. 119-133].

Sunal G., Satir M., Natal'in B., Toraman E., 2008. Paleotectonic Position of the Strandja Massif and Surrounding Continental Blocks Based on Zircon Pb-Pb Age Studies. International Geology Review 50 (6), 519-545. http://dx.doi. org/10.2747/0020-6814.50.6.519.

Teipel U., Eichhorn R., Loth G., Rohrmuller J., Holl R., Kennedy A., 2004. U-Pb SHRIMP and Nd Isotopic Data from the Western Bohemian Massif (Bayerischer Wald, Germany): 
Implications for Upper Vendian and Lower Ordovician Magmatism. International Journal of Earth Sciences 93, 782801. https://doi.org/10.1007/s00531-004-0419-2.

Tikhomirov P.L., Chalot-Prat F., Nazarevich B.P., 2004. Triassic Volcanism in the Eastern Fore-Caucasus: Evolution and Geodynamic Interpretation. Tectonophysics 381 (1-4), 119-142. http://dx.doi.org/10.1016/j.tecto.2003.10.014.

Ustaomer P.A., Ustaomer T., Robertson A.H.F., 2012. Ion Probe U-Pb Dating of the Central Sakarya Basement: A Peri-
Gondwana Terrane Intruded by Late Lower Carboniferous Subduction/Collision Related Granitic Rocks. Turkish Journal of Earth Sciences 21, 905-932. http://dx.doi.org/10. 3906/yer-1103-1.

Wanless V.D., Perfit M.R., Ridley W.I., Wallace P.J., Grimes C.B., Klein E.M., 2011. Volatile Abundances and Oxygen Isotopes in Basaltic to Dacitic Lavas on Mid-Ocean Ridges: The Role of Assimilation at Spreading Centers. Chemical Geology 287 (1-2), 54-65. https://doi.org/10.1016/j.chemgeo.2011.05.017. 